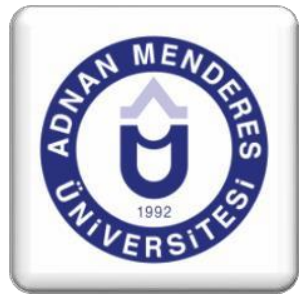

\title{
İlk Tunç Çă̆ı'nda Manisa Yöresi'nde Yerleşim Dokusu
}

Engin AKDENIZ ${ }^{1}$

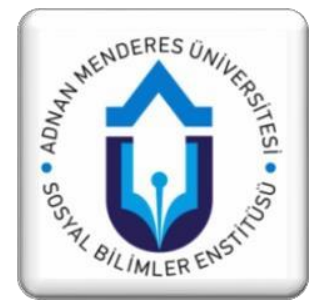

\section{ÖZET}

Bulunduğu coğrafi konumu ve doğal kaynakları dolayısıyla avantajlı bir durumdaki Manisa yöresinde erken dönemler içerisinde en yoğun buluntu merkezi, İlk Tunç Çağı'na aittir. Bu döneme ilişkin buluntular 92 merkezde saptanmıştır. Dönem içerisinde ise komşu bazı yörelerde olduğu gibi İlk Tunç Çağı'nın II. evresinde en yüksek seviyeye ulaşmıştır. Bir önceki dönem olan Son Kalkolitik Çağ seramiği tespit edilen merkezlerin hemen tamamında İlk Tunç Çağı I evresine ait buluntu da saptanmıştır. Dolayısıyla, Son Kalkolitik Çağ ile İlk Tunç Çağı I arasında kültürel bir kesinti görülmemekte, aksine devamlılıktan rahatlıkla söz edilebilmektedir. Bu devamlılık kültürel anlamda çanak çömlek parçalarının form ve teknik özelliklerinde de göze çarpmaktadır. Ayrıca İlk Tunç Çağı merkezlerinin önemli bir kısmında sonraki dönem olan Orta Tunç Çağı buluntusu da saptanmıştır. İlk Tunç Çağı'ndan Orta Tunç Çağı'na geçişte terk edilen buluntu merkezi az sayıdadır.

Anahtar Kelimeler: Yerleşim dokusu, İlk Tunç Çă̆ı, Manisa

\section{Settlement Patterns in Manisa Province in the Early Bronze Age}

\begin{abstract}
The most densely earliest find centers in Manisa province, which has an advantage due to its geographical location and natural resources, belong to the Early Bronze Age. Such findings are located in 92 centers. These findings reach their peak point in the second period of the Early Bronze Age. Certain neighboring regions have also found this to be the case. Findings from the Early Bronze Age are also located in almost all the centers where Late Chalcolithic Age (the previous age) ceramics were detected. Therefore, no cultural decrease was found between the Late Chalcolithic Age and Early Bronze Age I. On the contrary, continuity is observed. This continuity can also be seen in the formal, cultural and technical specifications of pots and jars. In addition, findings from the Middle Bronze Age (the next age) were also found in many of the Early Bronze Age centers. The number of the finding centers that were left during the transition from the Early Bronze Age to the Middle Bronze Age is quite limited.
\end{abstract}

Keywords: Settlement Pattern, Early Bronze Age, Manisa

\footnotetext{
${ }^{1}$ Prof.Dr.Engin Akdeniz, Adnan Menderes Üniversitesi, Fen-Edebiyat Fakültesi, Arkeoloji Bölümü, Aytepe-Aydin.
} 


\section{1)-Manisa Yöresi'nin Coğrafi Özellikleri}

Ege Bölgesi'nin Batı kesiminde, Menemen Boğazı yardımıyla denize oldukça yakın bir

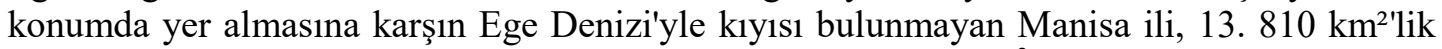
yüzölçümüyle birbirinden çok farklı coğrafi özelliklere sahiptir ${ }^{2}$. İl merkezinin yer aldığı güneybatı kesiminden başlayarak Saruhanlı üzerinden kuzeyde Akhisar'ın kuzeyine kadar uzanan alan ile doğuda Turgutlu, Ahmetli, Salihli ilçelerinden Alaşehir civarına kadar uzanan geniş arazi ilin diğer kısımlarına kıyasla 1lıman Ege iklimin hüküm sürdüğü topraklardır. Oysa, daha iç ya da yüksek kesimlerdeki Kula, Demirci, Selendi, Köprübașı, Gördes ile Soma ve Kırkağaç'ın bir bölümü karasal iklimin etkilerini belli ölçüde de olsa yansıtmaktadırlar. $\mathrm{Bu}$ birbirinden farklı nitelikteki alanların tarih içerisindeki kültürel yapılanmalarında günümüzde olduğu gibi farklılıklar gözlenmektedir. Bu durumun benzeri bir oluşumun, erken dönemlerde ve konumuz olan İlk Tunç Çağı'nda da yaşandığı hissedilmektedir. Günümüzde de yörenin bu farklı coğrafi özellikleri sebebiyle bir kısmı "Ege Bölümü”, bir kısmı ise "İçbatı Anadolu Bölümü" kapsamına girmektedir. Ege Bölgesi başlığı altında "Bakırçay Yöresi”, "Aşağı Gediz Yöresi”, İçbatı Anadolu Bölümü başlığı altındaysa "Gördes-Uşak Yöresi" incelenmektedir (Darkot-Tuncel, 1995: 20, 30).

Bunlardan kuzeydeki Bakırçay Yöresi, adını Antik dönemde Kaykos denilen Bakırçay’dan alır. Gelenbe yöresindeki İlk Tunç Çağı mezarlığı olan Yortan yakınlarından başlayan, aynı isimle anılan bu vadi tabanı, Kırkağaç-Soma yöresinde doğu batı doğrultusunda devam ederek Çandarl1-Dikili yöresinde arazinin ve dolayısıyla kültürlerin denizle buluşmasını sağlar. Bakırçay yöresindeki Madra Dağı $1344 \mathrm{~m}$. yüksekliğindedir. Gelembe Ovası, Kırkağaç Ovası ve Kınık Ovası'nın bir bölümü bölge sınırlarındaki başlıca ovalardır(DarkotTuncel, 1995: 34).

Aşağı Gediz Yöresi ise, Antik Çağda Hermos (Hermus) denilen Gediz Irmağı'nın suladığı Salihli-Manisa Ovası (Gediz Ovası adıyla da anılan) kesimini kapsar. Bu yöre, kuzeyde Salihli, güneydoğuda Sarıgöl civarından itibaren batıya doğru devam eder. Yörenin kuzey sınırını Gördes-Uşak yaylası, güney sınırını ise Bozdağlar (Tmolos, Tymolus, Timolus) çizmekte olup en geniş yeri Sipylos dağının doğu kesiminde olup $20 \mathrm{~km}$.'den fazladır (Darkot-Tuncel, 1995: 37). Bozdağlar'ın il sınırı içinde kalan en yüksek zirveleri $2070 \mathrm{~m}$. yüksekliğindeki Kumpınar Tepe ile 1148 m. yüksekliğindeki Gökbel Tepedir.

Aşağı Gediz Yöresi'nin en önemli dağı Yunt Dağıdır (Aspordene). Kuzey uzantısı Tarhala Dağı 1116 m. yüksekliğindedir. Yörenin güney sınırını oluşturan, Antik dönemde Sipylos Dağı, günümüzde ise bu adlandırmanın biraz değişerek Spil Dağı'na dönüşmesiyle isimlendirilen ya da Manisa Dağı da denilen kütle, aslında jeolojik açıdan batıda $1076 \mathrm{~m}$. yüksekliğindeki Yamanlar Dağı ile doğusundaki 1513 m.' lik Manisa Dağlarının uzantısıdır. Dağın kuzeybatı kısmında yer alan, yaklaşık 1400 m. yüksekliğindeki Atalanı mevkii, 1968 yılında milli park haline getirilmiştir. Yörenin güneydoğusundaki Uysal Dağı, Alaşehir Çayı'na paralel olarak uzanan, pek yüksek ve düzenli olmayan bir yükseltidir. Alaşehir'in güneyinde yer alan bu dağın en yüksek yeri 1135 m.dir.

Manisa ilinin Alaşehir-Salihli-Akhisar hattının doğusunda kalan tüm toprakları Gördes-Uşak Yöresi'nin bir kısmını oluşturmaktadır. İdari bakımdan Demirci, Kula, Selendi ve Gördes

\footnotetext{
${ }^{2}$ Yardım ve destekleri sebebiyle TÜBİTAK SOBAG’a, Kültür ve Turizm Bakanlığı Anıtlar ve Müzeler Genel Müdürlüğü’ne, DÖSİM’e, Manisa Müzesi Müdürlüğü’ne, Akhisar, Kula, Sarıgöl, Karakurt, Kayacık Belediye başkanlıklarına ve yöre halkına teşekkür ederim.
} 
ilçeleri bu yöre içerisinde değerlendirilmektedir. Burada dalgalı düzlükler 600-800 m. arasında değişse de yer yer 1000-1200 ve seyrek olarak 1550 m.'yi (Kula civarında) geçen yuvarlak sırtlara rastlanır (Darkot-Tuncel, 1995: 78). Gördes-Uşak platosu bu bölge içerisinde önemli bir coğrafyadır. Önemli yükseltiler, Demirci Dağları (Antik Temnos) adıyla anılmakta olup dağ sırasının en yüksek doruğunu, Demirci ile Simav arasında $1800 \mathrm{~m}$. yüksekliğindeki Ziyaret Tepe oluşturmaktadır. Yine yörenin en güneybatısında yer alan ve Gediz Nehri, Kumçayı ve Gölmarmara üçgeninde yükselen Çal Dağı, Demirci Dağları'nın kolları durumunda olan, Çomaklı Dağı ve Dibek Dă̆ı'nın güneybatı uzantısıdır. Dağ, ortasında oluşmuş bir çöküntü koridoru ile ikiye ayrılmaktadır. Batı kesimi daha geniş ve yüksek bir kütledir. Dağın en zirvesi batı kısmında yer alan 1034 m. yüksekliğindeki Aysekizi Tepedir.

Yöredeki en önemli iki akarsuyu yukarıda da belirttiğimiz üzere Gediz (Hermos/Hermus) ve Bakırçaydır (Kaykos). Her ikisi de doğu-batı doğrultusunda uzanır. Gediz Irmağı, 401 km.'lik uzunluğuyla Ege Bölgesi'nin Büyük Menderes'ten (Maiandros) sonraki ikinci büyük akarsuyudur. Gediz ve Bakırçay, günümüzde olduğu gibi eski çağlarda da bölgede pek çok kültürün gelişmesine olanak sağlamış, alüyval dolgu ya da yamaç erozyonuyla zenginleşen bereketli ovaları sulamışlardır. Bu ovaların önemli bir kısmı genellikle tektonik kökenli çöküntü sahalanıdır. Ülkemizin sayılı ovalarından olan Gediz Ovası, en geniş yeri Manisa Dağı'nın doğu yönünde $20 \mathrm{~km}$. olmak üzere Sarıgöl ile Menemen arasında $150 \mathrm{~km}$. civarında uzunluğa sahiptir (Darkot-Tuncel, 1995: 37). Bölgedeki en büyük olan Marmara Gölü’nün (Gyges Gölü, Gygean, Koloe) denizden yüksekliği 74 m., yüzölçümü ise 11,9 $\mathrm{km}^{2}$ 'dir. Göl, 320.000.000 $\mathrm{m}^{3}$ su depolama kapasitesine sahiptir. Buna karşın yanlış sulama başta olmak üzere çeşitli sebeplerle her geçen gün kapladığı saha azalmakta, suları çekilmekte ve kirlenmektedir. Bu durum göl ve çevresindeki ekolojik yapıyı tehdit etmektedir. Demirköprü Barajı ise yapay bir göldür. Bu gölün bir faydası da özellikle güneybatısındaki ovalık araziyi taşkınlardan korumasıdır. Bunu, Buldan ve Afşar barajları takip eder.

Manisa yöresinde modern yerleşimler genellikle ovada, daha az oranda dağ yamaçları ve dağların belli bir rakıma kadar olan seviyelerinde yer almaktadır. Ova yerleşimleri ticaret ve tarım, bazı merkezlerde ise sanayiye dayanan ekonomiye sahiptirler. Yamaç ve dağ yerleşimleri ise daha çok tarım ve hayvancılıkla geçinmektedir. Yamaç ve dağ yerleşimleri genelde köylerden oluşsa da yamaçlarda kasabalar (beldeler) da vardır. Ovada ise demiryolları ve karayolları tarımsal potansiyelin önüne geçmeye başlamış, köy, kasaba ve ilçeler bu güzergahlar üzerinde kümelenmiştir. Dağ köylerindeki fazla iş gücü yazın ovalardaki tarımsal arazilere inerek çalışırlar (Yakar, 2007: 278-279). Gediz, Akhisar, Bakırçay Ovaları başta olmak üzere ovalar, vadiler doğal yol güzergahlarını oluşturmaktadır. Eski devirlerde de birçok rotanın günümüzdeki kara ve demiryollarına paralel olması mümkündür. Yine aynı şekilde özellikle çok yüksek olmayan dağlar arasındaki kuzey-güney kestirme yolları farklı çöküntü ovaları arasında kolaylıklar ulaşımı sağlamaktadır.

\section{2)-Manisa Yöresinin Prehistoryası ve Protohistoryasıyla İlişkili Çalışmalar}

Ilıman Ege iklimiyle karasal iklimin çakıştığı, coğrafi konumu itibariyle uzak mesafeli düşünüldüğünde İç Anadolu ile Ege sahil şeridi, Güney Marmara ile Güney Ege arasındaki doğal güzergahın geçiş noktasındaki Manisa, tarımsal potansiyeli, ormanları, çeşitli yeraltı yataklarına sahip olmanın yarattı̆̆ avantajları ile insanlık tarihinin erken dönemlerinden günümüze kadar değişik halklar tarafından yerleşim yeri seçilmiştir. Antik devrin önemli 
kültürlerinden Lydia uygarlığının bu topraklarda yaşam bulması yukarıdaki faktörlerin bir sonucudur.

Ancak, bölgenin arkeolojik açıdan büyük bir potansiyele sahne olmasına karşın bu coğrafyadaki Prehistorya-Protohistorya amaçlı bilimsel çalışmalar, potansiyeliyle orantılı değildir. Manisa ili sınırları içerisinde bilinen ilk arkeolojik faaliyet, Osmanlı İmparatorluğu'nun hizmetinde bir demiryolu mühendisi olarak çalışan P.Gaudin ve Atina Fransız Okulu (sonraki adıyla Atina Fransız Arkeoloji Enstitüsü) görevlisi V. Chapot tarafindan Yortan mezarlığında gerçekleştirilmiştir. Kimine göre 1898 (Charloux, 2007: 24, 26), kimine göre ise 1900 yılındaki (Kamil, 1982: 1vd.) bu kazının yapıldığı mezarlık sahasının yeri zaman içerisinde unutulmuş ve yanlış lokalizasyonlar önerilmiştir. Yortan Mezarlığı'nın Kırkağaç ilçesi Gelenbe (Gelembe) beldesi yakınlarındaki Bostancı (Yortan) Köyü sınırlarında yer alan Taban Tepe'de olduğu araştırmalarımızla tespit edilmiştir (Akdeniz, 2009: 49 vd.).

Anadolu Arkeolojisi'ne büyük katkılar sağlayan K.Bittel'in 1942'de Alman Arkeoloji Enstitüsü adına yaptığı çalışmalarda Manisa ili sınırlarında, Kırkağaç yakınlarındaki Maltepe ve Soma'daki höyükler ele alınmıştır (Bittel, 1942: 174). Ankara İngiliz Arkeoloji Enstitüsü Müdürlüğü görevini yürüten D.H.French 1959-1960 yılları arasında Balıkesir ve Manisa/Akhisar yöresindeki arazilerde yüzey araştırması yapmıştır. Bu çalışmalar sonucunda bölgede çok sayıda Prehistorik-Protohistorik buluntu merkezi tespit edilmiştir (French, 1969: 41-91). Sardis'de daha çok geç dönem kültürlerine yönelik çalışmalar sırasında konumuz olan dönemlerle ilişkili sınırlı bazı verilere ulaşmak mümkün olmuştur (Hanfmann, 1951: 160 vd.; Hanfmann, 1983: 17-25; Ramage, 1994: 163-165; Greenewalt-Rautman, 1998: 362). Marmara Gölü (Gyges Gölü, Gygean, Koloe) kıyısındaki Eski Balıkhane ve Ahlatlı Tepecik'de yapılan kısa süreli A.B.D.-Türk kazıları ise özellikle İlk Tunç Çağı ölü gömme geleneklerinin anlaşılması için katkı sağlamıştır (Greenewalt-Sullivan-Rate-Howe, 1983: 64; Greenewalt, 2006: 362; Roosevelt, 2009: 207). Bunlardan Ahlatl1-Tepecik 1967 ve 1968 yılında D.G. Mitten yönetiminde, J.S. Hendersen ve G. Yüğrüm'ün katılımıyla kazılmıştır. Eski Balıkhane'deki kazı ise 1969 yılında Sardis'de çalışan Harvard Cornell Arkeolojik Araştırmaları çerçevesinde D.G. Mitten yönetiminde, D.H. Finkel ve M. Dağtekin'in katılımıyla sondaj niteliğinde gerçekleştirilmiştir. Buradaki kazılar sonucunda M.Ö. III. bin yıla tarihlenen 5 tane küp mezar açığa çıkartılmış ve ölü gömme gelenekleri hakkında bilgi edinilmiştir (Mitten-Yüğrüm, 1968: 126, 127, 129, 130; Mitten-Yüğrüm, 1969: 192-195; Mitten-Yüğrüm, 1974: 22-29; Roosevelt, 2009: 207).

Alaşehir yakınlarındaki Gavurtepe Höyüğünde kazılar 1987-1992 yılları arasında R. Meriç sürdürülmüştür. Bu kazılar sırasında höyükte, Kalkolitik Çağ'dan başlayarak kuvvetli bir İlk Tunç Çağı ve sürpriz özelliklere sahip MÖ 2. Binyıl kültürlerine ulaşılmıştır. Ancak bu kazı ne yazık ki yarım kalmıştır (Meriç, 1989: 1989, 157-170; Meriç, 1990: 179-190; Meriç, 1992: 227-235). Meriç, bu kazının yanı sıra gerek İzmir, gerekse Manisa illerinde sürdürdüğü yüzey araştırmalarında French'in saptadığı yerleşimlere ilaveten yeni merkezler de tespit edilmiştir (Meriç, 1990: 361-366).

Bölgenin erken dönem kültürlerine yönelik olarak gerçekleştirilen sonraki bir çalışma R. Dinç'e aittir. 1991 tarihli Erdelli Höyük yayınının (Dinç, 1991: 1991), 27, 28, 36) ardından, 1994-1995 yıllarında özellikle Kumçayı (Hyllos), Bakırçay (Kaikos) ile Gördükçayı (Lykos) ırmaklarının suladığı Akhisar çevresindeki araştırmaları sırasında Kulaksızlar atölyesine önem verilmiş ve bu mermer-taş figürin-kap atölyesinde ayrıntılı çalışmalar yapılmıştır (Dinç, 1996: 11-41; Dinç, 1997: 255-282). Dinç'den sonra T. Takaoğlu söz konusu arazide 
başka bir çalışma gerçekleştirerek, önceden Dinç tarafindan toplananlar da dahil olmak üzere yüzey buluntularına dayalı bir Doktora tezi ve kitap hazırlamıştır (Takaoğlu, 2005: 1 vd.). Roosevelt'in 2000 y1lından itibaren merkezi Lydia bölgesi başta olmak üzere sürdürdüğü araştırmalar yörenin geç dönemlerinin yanı sıra erken dönemleri hakkında da önemli bilgiler vermektedir (Roosevelt 2006; 61 vd.; Roosevelt 2009; 11vd.; Roosevelt-Luke 2009; 441, 442). Bölgede 2007 yılından itibaren başlattığımız çalışmalarının amacı, daha evvel sınırlı kesimleri incelenen bölgeyi, alt coğrafi yöreleri de dikkate alarak bir bütün halinde ve başlangıcından Antik Yunan dönemi öncesine kadar genel hatlarıyla değerlendirmek olmuştur.

\section{3)- İlk Tunç Çağı'nda Manisa Yöresi'nde Yerleşim Dokusu}

$\mathrm{Bu}$ çalışmalar sonucu 104 merkezde Prehistorik ve Protohistorik buluntuya rastlanmıştır (Res. 1). Bu devirler içerisinde en yoğun buluntu merkezi, konumuz olan İlk Tunç Çağı'ndadır. Bu döneme ilişkin buluntular 92 merkezde saptanmıştır (Res. 2). Bölgede en yoğun iskan bu döneme ait olup dönem içinde de komşu diğer bölgelerde olduğu gibi II. evresinde doruğa ulaştı̆̆ı anlaşılmaktadır. Dönemsel karşılaştırma yapıldığında Son Kalkolitik Çağ malzemesi bulunan merkezlerin hemen tamamında bu döneme ait buluntu da saptanmışıı. Bir başka ifadeyle, Son Kalkolitik Çağ ile İlk Tunç Çağı arasında kültürel bir kesinti görülmemekte, aksine bir devaml1lıktan rahatlıkla söz edilebilmektedir. $\mathrm{Bu}$ devamlılık kültürel anlamda çanak çömlek parçalarının form ve teknik özelliklerinde de göze çarpmaktadır. Ayrıca İlk Tunç Çağı merkezlerinin önemli bir kısmında sonraki dönem olan Orta Tunç Çağı buluntusu da saptanmıştır. İlk Tunç Çağı'ndan Orta Tunç Çağı'na geçişte terk edilen buluntu merkezi sayısı çok azdır. Manisa yöresinde ilk defa İlk Tunç Çağı'ndan itibaren yerleşim dışı mezarlıklar tespit edilmiştir. Buna karşın saptanabilen mezarlık sayısı dördü geçmez. Bu mezarlıkların üçü Kula, biri ise Kırkağaç çevresindedir. Mezarlıklar arasında en bilineni "Yortan Mezarlığı" adıyla tanınan "Taban Tepe mezarlığıdır (Akdeniz 2009; 49 vd.). Yüzey araştırmalarımız sırasında ilk defa kesin yeri tespit edilebilen bu mezarlık hakkındaki en önemli sorun ait olduğu yerleşim (ler?-ortak mezarlık?)in kesin olarak bulunamamasidır.

İlk Tunç Çağında yüzey araştırmalarında tespit edilen buluntu merkezlerinin modern yerleşim yerlerine göre dağılımına bakıldığında, merkez sayısı Akhisar ve çevresindeki arazide 26, Kula ve çevresinde 25, Kırkağaç ve çevresinde 12, Saruhanlı ve çevresinde 10, Manisa il merkezi çevresinde 3, Alaşehir ve çevresinde 5, Demirci ve çevresinde 2, Turgutlu ve Gölmarmara çevresinde 1, Gördes ve çevresinde 3, Sarıgöl ve çevresinde 2, Selendi ve Soma çevresinde ise 1'dir.

İlk Tunç Çağı'na tarihlenen yüzey buluntusu saptanan 92 merkezin 60'ı (\% 65'i) höyük, 12 'si (\% 13'ü) tepe üstü yerleşim, 8'i (\% 9'u) yamaç yerleşimi, 11'i (\% 12'si) mezarlık, biri olası atölyedir alanıdır (Res. 3). Bu merkezlerden höyüklerin 19'u (\% 33) Akhisar çevresi, 12'si (\% 19) Kula çevresi, 7'si (\% 11) Kırkağaç çevresi, 7'si (\% 11) Saruhanlı çevresi, 3’ü (\% 5) Manisa İl Merkezi çevresi, 3’ü (\%5) Alaşehir, ikişer tanesi (\% 3), Gördes, Sarıgöl, birer tanesi (\% 2) Demirci, Selendi, Gölmarmara, Turgutlu ve Soma çevresinde tespit edilmiştir. İlk Tunç Çağ 1 höyüklerinin önemli bir kısmı doğal yol güzergahlarının çevresinde konumlanmıştır. Saptanan 12 tepe üstü yerleşimden 4'ü (\% 34) Kula, 3’ü (\% 25) Kırkağaç, 3'ü Saruhanl, 1'i (\% 8) ise Alaşehir, 1'i Gördes çevresindedir. Yamaç yerleşimi sayısı 8 olup bunun 4'ü (\% 49) Akhisar çevresi, 3’ü (\% 38) Kula, 1’i (\% 13) Alaşehir çevresindedir. 
Mezarlık sayısı 11 olup 6'sı (\% 55) Kula çevresi, 2'si (\% 18) Akhisar, 2'si (\% 18) Kırkağaç, biri de (\% 9) Demirci çevresindedir. Doğal yol güzergahı üzerinde yer alan höyükler arasında, bugünkü güzergahlarla yaklaşık aynı istikamette olduğu düşünülen yolların kıyısında kümelenen, Akhisar yakınlarındaki Dağdeviren Höyüğü, Kennez Höyüğü, Saruhanlı yakınlarındaki Bedeller Höyüŭü, Soma yakınlarındaki Yağcılı Höyüğü, Manisa il merkezi yakınlarındaki Baklatepe Höyüğü en dikkat çekenlerdir. Bunlardan Dağdeviren Höyüğü (Resim 4 ve 5), Akhisar ilçe merkezinin konumlandığı noktada, kuzey-güney doğrultulu günümüz karayolunun ve ona paralel uzanan demiryolunun da batı kıyısında yer almaktadır ${ }^{3}$. Akhisar'ın güneydoğusundaki Kennez Höyüğü ise, antik Çağlarda Thyateira ile Sardeis arasındaki ana yolun (bugünkü Akhisar-Gölmarmara üzerinden devam eden yol) kıyısındadır (Resim 6 ve 7). Akhisar İlçe merkezindeki Hastane Höyüğ̈̈'nde 2012 yılında başlayıp 2013 y1lında yoğunlaşılarak devam eden kazılarda hem L28, hem de M28 açmalarında İlk Tunç Çağı'na ait birkaç evre tespit edilebilmiştir. L28'de, $107.830 \mathrm{~m}$. seviyesinde başlayan kazılarda 102.500 seviyesinde bir yangın tabakasına rastlanmıştır. Devam eden seviye indirme çalışmalarında plankarenin kuzey doğu kesitinde $101.080 \mathrm{~m}$. seviyesinde yaklaşı $100 \mathrm{~cm}$. boyunda, $25 \mathrm{~cm}$. kalınlığında kesme taşlardan oluşan ve belli bir düzleme oturtulduğu anlaşılan taş duvar tespit edilmiştir. Bu duvar ve çevresinde İlk Tunç Çağı'na ait seramik parçaları ele geçmiştir. Bu açmada amaç ana kayaya ulaşmak olsa da ilerleyen kazı evrelerinde heyelan tehlikesine karşı 99.88 m.'de kazı tamamlanmıştır (Akdeniz, 2012: 21-44).

Hem Hastane Höyüğü'nün hem de Dağdeviren Höyügü'nün lokalizasyon sebepleri arasında diğer faktörlerin yanı sıra günümüzde olduğu gibi ulaşıma yönelik konumu da rol oynamış olmalıdır. Bedeller Höyüğü ise (Resim 8 ve 9), Saruhanl1-Gölmarmara arasındaki batı-doğu doğrultulu doğal yolun kıyısındadır. Baklatepe Höyüğü, Manisa Ovası ile Menemen Boğazı ve Ovası, dolayısıyla Ege sahil şeridi arasındaki güzergahın (Resim 10 ve 11), Yağcılı Höyüğü ise Soma-Bakırçay Havzası ile kuzeyindeki Savaştepe arasındaki doğal yol güzergahı kıyısındadır (Resim 12 ve 13).

İlk Tunç Çağı höyüklerinin kapladıkları saha 0,6 hektar ila 18 hektar arasında değişmektedir (Res. 14). Bu dönemde tespit edilen 60 höyükten 36 tanesinin sahas1 1 hektarın üzerindedir. 1 hektarın altındaki alana sahip höyüklerin boyutları ise 0,6 hektar ile 0,96 hektar arasında değişmektedir. Son Kalkolitik Çağ'da tespit edilen höyüklerin yarısından fazlasının kapsadığı saha 1 hektarın altındayken, İlk Tunç Çağı'nda bu oran tam tersi yönde değişerek tespit edilen höyüklerin yarısından fazlasının alanının 1 hektardan fazla olduğu görülmektedir.

Önceki dönemlerde de merkezi bir yerleşim olduğu düşünülen Selendi yakınlarındaki Ters Tepe Höyügü 18 hektarlık boyutuyla bu dönemin en büyük höyük yerleşimi olarak karşımıza çıkmaktadır (Res. 15). Ters Tepe'den sonra dönemin en büyük diğer höyük yerleşimleri Kula yakınlarındaki Söğütçayı (8,75 hektar), Demirci yakınlarındaki Bozyer Höyüğü (7,5 hektar), Sarıgöl yakınlarındaki Kızılçukur Höyüğü (7,5 hektar), Akhisar yakınlarındaki Akselendi Höyüğü (7 hektar), Çamönü Höyüğü (5 hektar), Süleymanlı Höyügü̈ (5 hektar),

3 İzmir-İstanbul otoyolu Akhisar bağlantısı yakınındaki Dağdeviren Höyüğü'nün kuzeydoğu uzantısında 2017 yılında Manisa Müzesi tarafından bir kazı gerçekleştirilmiştir. Henüz yayınlamamış bu kazıda İlk Tunç Çağı'na tarihlenen mezarlar tespit edilmiştir. Verdiği bilgilerden dolayı kazı görevlilerine teşekkür ederim. 
Kula yakınlarındaki Şeremet Kavaklı Höyüğü (6 hektar), Üç Kuyular Höyüğü (6 hektar), Gölcük Höyük (5,4 hektar), Bademyaka (Körez) Höyüğü (5 hektar), Sarı Balıklı Gö1 Höyüğü (5 hektar), Kırkağaç ve çevresindeki Maltepe Höyüğü (6 hektar), Azizkuyusu Höyüğü $(5,95$ hektar), Turgutlu yakınlarındaki Asartepe (6 hektar) olarak sıralanmaktadır. İlk Tunç Çağı'na ait büyük höyüklerin boyutlarının birbirine oldukça yakın, bazılarının aynı olduğu görülmektedir. $\mathrm{Bu}$ dönemde saptanan en küçük sahaya yayılan höyükler ise Kırkağaç yakınlarındaki Sakarcalı Höyük ve Saruhanlı yakınlarındaki Alibeyli Höyügüüür. Her iki höyüğün de boyutları 0,6'şar hektardır. Bu yerleşimleri Soma yakınlarındaki Üyücek Tepe (Yağcılı) Höyüğü (0,7 hektar) yine Saruhanlı yakınlarında yer alan Lütfiye (Arpalı I) $(0,8$ hektar), Manisa il merkezi ve çevresinde yer alan Baklatepe (0,8 hektar) ve Tekeliler Höyüğü $(0,9$ hektar) izlemektedir.

İlk Tunç Çağı ile birlikte tepe üstü yerleşimlerin sayısında da önemli bir artış görülmektedir. Kula ve çevresinde 4, Kırkağaç ve çevresinde 3, Saruhanlı ve çevresinde 3, Alaşehir ve Gördes çevresinde 1, toplam 12 tepe üstü yerleşim yeri tespit edilmiştir. Bu yerleşimlerin kapladıkları saha 0,35 ila 6 hektar arasında değişmektedir. Bu yerleşimlerden Neolitik ve İlk Kalkolitik Çağ yerleşimi barındıran 6 hektarlık büyük bir yerleşim olan Koldere, Neolitik ve Son Kalkolitik iskanı barındıran 0,48 hektarlık Naimtepe ve 0,35 hektarlık bir araziye yayılmış Son Kalkolitik Çağ yerleşimi Çitlenbiktepe'de iskan bu dönemde de devam etmiştir.

İlk Tunç Çağ 1 tepe üstü yerleşimlerinin geniş arazilere yayılmış olduğu gözlenmektedir. 12 yerleşim merkezinin 7 tanesinin kapsadığı saha 1 hektarın üzerindedir. Özellikle Kula yakınlarındaki Narince Pıtırak ve Gökçeören Samanlık mevkii Manisa yöresi için yeni bir yerleşim modeli olarak karşımıza çıkmaktadır. Bu iki merkez, alışılmış İlk Tunç Çağı yerleşimlerinden farklıdır. Narince Pıtırak deniz seviyesinden 945 m., Gökçeören Samanlık Mevkii ise $846 \mathrm{~m}$. yüksekliktedir. Dolayısıyla Kula yöresinde birbirine yakın konumdaki bu iki yerleşimin, yörede aynı döneme ait ova yerleşimlerinin de varlığına karşın deniz seviyesinden bu kadar yüksekte yer almaları güvenlik kaygılarından çok sosyoekonomik durumlarıyla ilgili olabilir. Bu merkezlerde yoğun bir şekilde üç ayaklı kaplara rastlanması da bu durumla bağlantılıdır. Her iki yerleşim İlk Tunç Çağı'nda Manisa yöresinde yayla kültürüne ait şimdiye kadar saptanan ilk yerleşim izlerini yansıtmaktadır. Bu iki yerleşimde Koldere yerleşiminde olduğu gibi 6 hektarlık bir alan üzerinde yer almaktadır. Bu tepe üstü yerleşimleri dışında dönemin diğer büyük tepe üstü yerleşimleri ise Kula yakınlarındaki Manastır Tepe (5 hektar), Tijen Tepe (3,4 hektar), Kırkağaç yakınlarındaki Değirmentepe II (3,92 hektar) ve Gördes yakınlarındaki Kozlucadır (2,16 hektar). İlk Tunç Çağı döneminin en sınırlı alanı kapsayan tepe üstü yerleşimi ise Alaşehir yakınlarındaki Taşlı Tepedir $(0,4$ hektar) (Resim 16). Bu döneme ait diğer tepe üstü yerleşimlerinin kapladıkları saha ise yaklaşık 1 hektar civarında değişmektedir.

İlk Tunç Çağı'nda diğer yerleşim modellerinde olduğu gibi yamaç yerleşimi sayısı da bir önceki döneme göre artış göstererek 8'e yükselmiştir. Bu yerleşimlerin 4 tanesi Akhisar, 3 tanesi Kula ve 1 tanesi Alaşehir civarında bulunmaktadır. $\mathrm{Bu}$ dönemde yamaç yerleşimlerinin kapladıkları saha 0,45 ila 10 hektar arasında değişmektedir. İlk Tunç Çağı yamaç yerleşimleri önceki dönemlere göre daha geniş bir yerleşim alanına sahiptir. 8 yerleşimden 5 tanesinin sahası 1 hektarın oldukça üzerinde 3 tanesinin ise 1 hektarın altındadır. Özellikle Alaşehir yakınlarındaki Gülistan yerleşimi kapladığı 10 hektarlık arazi ile oldukça dikkat çekici özelliktedir. Gülistan dışında dönemin diğer büyük tepe üstü yerleşimleri Kula yakınlarındaki, Erenbağı (6 hektar) (Resim 17), Son Kalkolitik Çağ'ın tek yamaç yerleşimi olan İncesu'da bu dönemde de devam eden yerleşim (6 hektar) yine Kula 
yakınlarındaki Kızıl Tepe $(2,4$ hektar) ve Akhisar yakınlarında yer alan Neolitik ve İlk Kalkolitik Çăg iskanı da barındıran Su Deliği bu dönemde de iskan edilmiştir. Akhisar yakınlarındaki, Deve Tepe, Kazım Çeşme (Resim 18) ve Durasıllı Yelli Gedik yerleşimleri 1 hektarın altındaki sahayı kaplayanlar dönemin küçük yamaç yerleşimleri olarak karşımıza çıkmaktadır.

İlk Tunç Çağı ile birlikte ölü gömme adetlerine ait izler belirginleşmeye başlamıştır. $\mathrm{Bu}$ dönemle birlikte bir ilk olarak 11 adet mezar alanı karşımıza çıkmaktadır. Bu mezar alanları Akhisar ve çevresinde 2, Kula ve çevresinde 6, Kırkağaç çevresinde 2, Demirci ve çevresinde 1'dir. İlk Tunç Çağı'na ait mezar alanları arasında en önemlisi hiç kuşkusuz literatüre Yortan Mezarlığı olarak giren Kırkağaç yakınlarındaki Taban Tepe'nin etekleridir (Resim 19). Taban Tepe'nin eteklerinde 4,2 hektarlık bir araziye yayılmış olan mezarlık alanı, sadece Manisa yöresinde değil, komşu coğrafyalar da dahil olmak üzere daha geniş bir alanda İlk Tunç Çağı'na ait ölü gömme adetlerini yansıtan en önemli mezarlık alanıdır. Bununla birlikte Kula yakınlarındaki Akkaya Mevkii (4,5 hektar) ve Yaylak Höyük Mezarlığı (2,6 hektar), Gölcük Höyük Mezarlığı (3 hektar) ve Sarı Balıklı Göl Mezarlığı (3 hektar) bölgedeki diğer önemli büyük mezarlık alanlarıdır. Özellikle Sarı Balıklı Göl Höyüğü'ne ait olduğu düşünülen mezar alanının yapısı ilgi çekicidir. Mezar alanı yüksek ve kayalık bir arazide bulunmakta ve mezar küplerinin ana kaya üzerine oturtulduğu düşünülmektedir. Bu döneme ait diğer mezar alanlarının kapladıkları saha 0,8 ila 1,5 hektar arasında değişmektedir. Saptanan en küçük mezarlık alanı 0,8 hektarlık alana yayılmış olan Akkuş Tepe Mezarlığıdır. Saptanan mezarlık alanlarının büyük bir kısmı, 1 hektar ile 4,5 hektar arası değişen boyutlarıyla İlk Tunç Çağı'na ait çoğu höyükten daha geniş bir alanı kaplamaktadır.

\section{4)-SONUÇ}

Sonuç olarak Manisa ilinin kapladığı topraklarda İlk Tunç Çağı'na tarihlenen 92 buluntu merkezi tespit edilmiş olup \% 65'i oluşturan 60 tanesi höyük, \% 13'ünü oluşturan 12'si tepe üstü yerleşimi, \% 9'unu oluşturan 8'i yamaç yerleşimi, \% 12'sini oluşturan 11'i mezarlık sahası, biri ise olası atölyedir alanıdır. Günümüz idari yapılanmasına bakıldığında ise, bu merkezlerden höyüklerin 19'u (\% 33) Akhisar çevresi, 12'si (\% 19) Kula çevresi, 7'si (\% 11) Kırkağaç çevresi, 7'si (\% 11) Saruhanlı çevresi, 3'ü (\% 5) Manisa İl Merkezi çevresi, 3’ü (\%5) Alaşehir, ikişer tanesi (\% 3), Gördes, Sarıöl, birer tanesi (\% 2) Demirci, Selendi, Gölmarmara, Turgutlu ve Soma çevresinde tespit edilmiştir. İlk Tunç Çağı höyüklerinin önemli bir kısmı doğal yol güzergahlarının çevresinde konumlanmıştır. Saptanan 12 tepe üstü yerleşimden 4'ü (\% 34) Kula, 3’ü (\% 25) Kırkağaç, 3'ü Saruhanlı, 1’i (\% 8) ise Alaşehir, 1’i Gördes çevresindedir. Yamaç yerleşimi sayıs1 8 olup bunun 4'ü (\% 49) Akhisar çevresi, 3'ü (\% 38) Kula, 1'i (\% 13) Alaşehir çevresindedir. Mezarlık sayıs1 11 olup 6's1 (\% 55) Kula çevresi, 2'si (\% 18) Akhisar, 2'si (\% 18) Kurkağaç, biri de (\% 9) Demirci çevresindedir.

Bir sonraki dönem olan Orta Tunç Çağı'nda ise Manisa yöresinde Orta Tunç Çăğ'na tarihlenebilecek buluntu merkezi sayıs1 azalarak 33'e iner (Res. 20). Bu merkezlerden 12'si Akhisar, 7'si Saruhanl1, 3'ü Alaşehir, 3'ü Kula, 2'si Manisa İl Merkezi çevresi, birer tanesi Soma, Turgutlu, Gölmarmara, Selendi, Demirci ve Kırkağaç yöresindedir. Yerleşim şekline göre ise 33 merkezden 30’u (\% 94) höyük, 3’ü (\% 6) ise tepe üstü yerleşimidir. Bu döneme tarihlenebilecek buluntu veren sadece bir yamaç yerleşimi tespit edilememiştir. 30 höyüğün 12'si (\% 43) Akhisar, 4’ü (\% 13) Saruhanlı, 3’ü (\% 10) Kula, 3’ü (\% 10) Alaşehir, 2’si (\% 6) 
Manisa İl Merkezi çevresi, birer tanesi (\% 3) ise Soma, Turgutlu, Gölmarmara, Selendi, Demirci ve Kırkağaç çevresindedir.

Orta Tunç Çăğ'nın en belirgin yerleşim modelini höyükler oluşturacaktır. Orta Tunç Çağı yerleşimi tespit edilen höyüklerin boyutları 0,5 ila 18 hektar arasında değişmektedir. $\mathrm{Bu}$ höyüklerin 18 tanesinin kapladığı alan 1 hektarın üstündedir. Kapladığı saha 1 hektarın altında olan höyüklerin alanı 0,5 hektar ile 0,96 hektar arasında değişmektedir. İlk Kalkolitik Çağ'da yerleşim gören, İlk Tunç Çağı'nda da yerleşim gördüğü anlaşılan, 18 hektarlık alanıyla yörenin en büyük merkezi yerleşimi olan Selendi yakınlarındaki Ters Tepe, Orta Tunç Çağı'nda da bu özelliğini koruyacaktır (Resim 15). Bu dönemde Son Kalkolitik Çağ'dan beri iskan gören Kula yakınlarındaki Sögü̈tçayı Höyüğü 8,75 hektarlık alanıyla yörenin ikinci büyük yerleşimidir. Söğütçayı Höyügü̈nü 7,5 hektarlık alanıyla Demirci yakınlarındaki Bozyer Höyüğü, Kırkağaç yakınlarındaki Maltepe Höyüğü (6 hektar), Turgutlu yakınlarındaki Asartepe (6 hektar), Akhisar yakınlarındaki Çamönü Höyügü (5 hektar) ve Süleymanlı Höyüğü (5 hektar) takip etmektedir. Dönemin büyük höyüklerinin boyutlarının birbirine yakın oluşu dikkat çekici bir özelliktir. 


\section{KAYNAKÇA}

AKDENIZ, E. (2009). "Yortan Mezarlığ1 Hakkında Yeni Gözlemler", Türkiye Bilimler Akademisi Arkeoloji Dergisi, TÜBA-AR, Say1 12 (2009), 49-64.

AKDENIZ, E. (2012). "Kuzey Lydia'daki Thyateira'nın Erken Dönem Yerleşimi: 'Hastane Höyüğü Kazısı"', Türkiye Bilimler Akademisi Arkeoloji Dergisi, TÜBA-AR, Say1 15 (2012), 21-45.

BİTTEL, K. (1942). Kleinasiatische Studien, İstanbul, 1942.

CHARLOUX, G. (2001). G.Charloux, "Paul Gaudin et les premières campagnes de fouilles à Yortan et à Aphrodisias", Orient Express 2001/1, 24-26.

DARKOT, B.-TUNCEL, M. (1995). B.Darkot-M.Tuncel, Ege Bölgesi Coğrafyası, İstanbul, 1995.

DİNÇ, R. (1991). "Erdelli Höyük und die Bedeutung seiner Funde für dieFrühbronzezeitliche Geschichte des Manisa-Akhisar Gebietes", Istanbuler Mitteilungen 41 (1991), 25-38.

DİNÇ, R. (1996). "1994 Yılı Akhisar-Kulaksızlar Mermer İdol Atölyesi Yüzey Araştırması”, XIII.Uluslararası Araştırma Sonuçları Toplantısı, 2. cilt, Ankara, 1996, 11-41.

DİNÇ, R. (1997). "Kulaksızlar Mermer İdol Atölyesi ve Çevre Araştırmaları", XIV. Araştırma Sonuçları Toplantısı, Ankara, 1997, 255-282.

FRENCH,D.H. (1969). "Prehistoric Sites in Northwest Anatolia II. The Balıkesir and Akhisar/Manisa Areas," Anatolian Studies 19 (1969), 41-98.

HANFMANN, G.M.A. (1951). "Prehistoric Sardis", Studies to David M.Robinson I, (Ed.G.E.Mylonas), St Louis, 1951, 160-183.

HANFMANN, G.M.A. (1983). Sardis from Prehistoric to Roman Times, Results of the Archaeological Exploration of Sardis 1958-1975, Cambridge, Massachusetts, 1983.

GREENEWALT, C.H. (2006). "Sardis", BYZAS 3, Stadtgrabungen und Stadtforschung im westlichen Kleinasien, (Ed.W.Radt), İstanbul, 2006, 359-372.

GREENEWALT, C.H. - RAUTMAN, M.L. (1998). "The Sardis Campaigns of 1994 and 1995", American Journal of Archaeology 102/3 (1998), 469-505.

GREENEWALT, C.H. -SULLIVAN,RATE， C.J.-D.G.-HOWE，T.N. (1983). "Sardis, 1981 and 1982", Türk Arkeoloji Dergisi XXVI-2 (1983), 152-215.

KAMiL, T. (1982). T.Kamil, Yortan Cemetery in the Early Bronze Age of Western Anatolia, British Archaeological Reports, BAR 145, Oxford, 1982.

MERİÇ, R. (1989). "1987 Yı1ı Alaşehir Kazısı", X. Kazı Sonuçları Toplantısı, 1. cilt, Ankara, 1989, 157-170.

MERİÇ, R. (1990a). "1988 Yılı Alaşehir Kazısı”, XI. Kazı Sonuçları Toplantısı, 1. cilt, Ankara, 1990, 179-190.

MERİÇ, R. (1990b). "1988 Yılı İzmir, Manisa İlleri Arkeolojik Yüzey Araştırması”, VII. Araştırma Sonuçları Toplantısı (1990), 361-366.

MERİÇ, R. (1992). “1990 Yılı Alaşehir Kazısı”, XIII. Kazı Sonuçları Toplantısı, I. cilt, Ankara, 1992, 227-235.

MERIÇ, R. (1993). "Pre-Bronze Age Settlements of West-Cental Anatolia (an extended abstract)", Anatolica XIX (1993), 143-150.

MITTEN, D.G.-YÜĞRÜM, G. (1968). "Excavation at Ahlatlı Tepecik on the The Gygean Lake, $\quad 1968$ ", Türk Arkeoloji Dergisi XVII-1 (1968), 125-127.

MiTTEN, D.G.-YÜĞRÜM, G. (1969). "The Gygean Lake, 1969: Eski Balıkhane, Preliminary Report", Harvard Studies in Classical Philology, Vol. 75 (1969), 191-195;

MITTEN, D.G.-YÜĞRÜM, G. (1974). "Ahlatlı Tepecik, Beside the Gygean Lake," Archaeology, 27-1 (1974), 22-29. 
RAMAGE, A. (1994). A.Ramage, "Early Iron Age Sardis and Its Neighbours", The Proceedings of the Third Anatolian Iron Ages Colloquium, (Ed.A.ÇilingiroğluD.H.French), (Van, 6-12 August 1990), Londra, 1994, 163-172.

ROOSEVELT, C.H. (2006). "Tumulus Survey and Museum Research in Lydia, Western Turkey: Determining Lydian-and Persian-Period Settlement Patterns", Journal of Field Archaeology Vol. 31 (2006), 61-76.

ROOSEVELT, C.H. (2009). The Archaeology of Lydia, From Gyges to Alexander, Newyork, 2009.

ROOSEVELT, C.H.-Luke,C. (2009). "Central Lydia Archaeolological Survey: 2007 Results", 26. Araştırma Sonuçları Toplantısı, 2. Cilt, Ankara, 2009, 433-450.

TAKAOĞLU, T. (2005). A Chalcolithic Marble Workshop at Kulaksizlar in Western Anatolia, BAR International Series, Oxford, 2005.

YAKAR, J. (2007). Anadolu'nun Etnoarkeolojisi (Çev. S.H.Riegel), İstanbul, 2007. 


\section{EKLER}

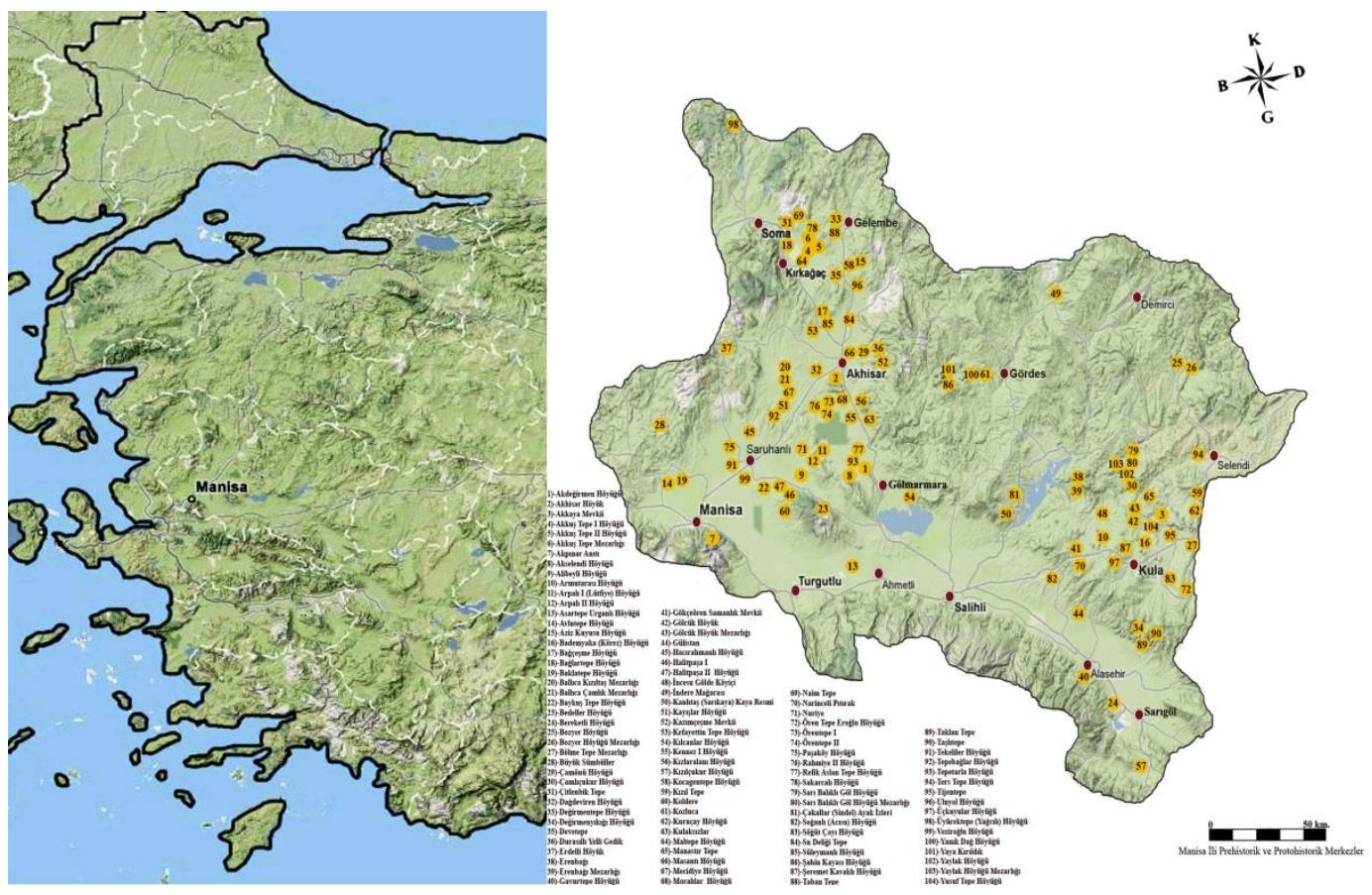

Res. 1 Manisa Yöresindeki Prehistorik-Protohistorik Buluntu Merkezleri 


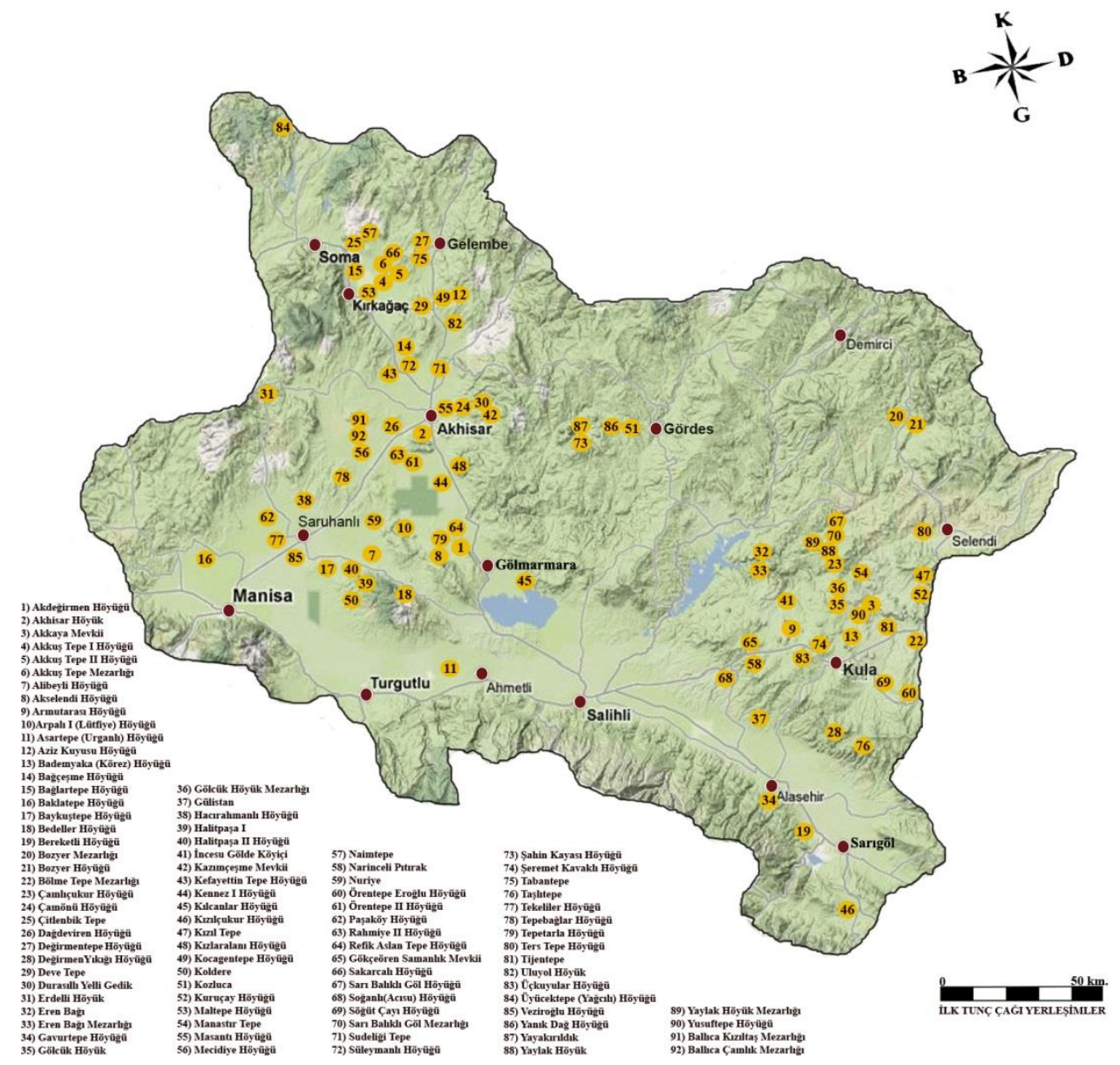

Res.2-Manisa Yöresinde İlk Tunç Çağı Buluntu Merkezleri 


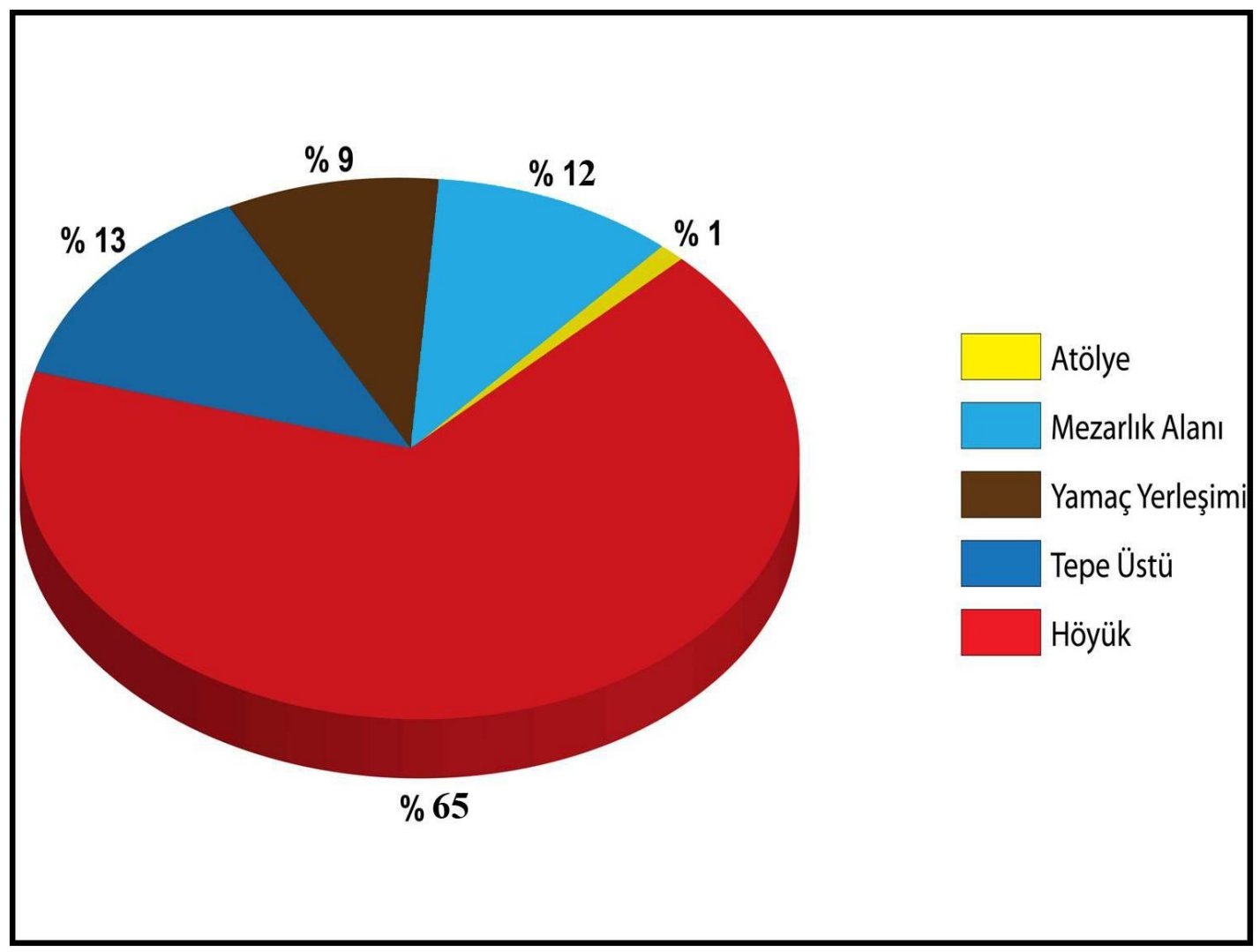

Res. 3 Manisa Yöresinde İlk Tunç Çağı Buluntu Merkezlerinin Tiplerine Göre Dağılımı

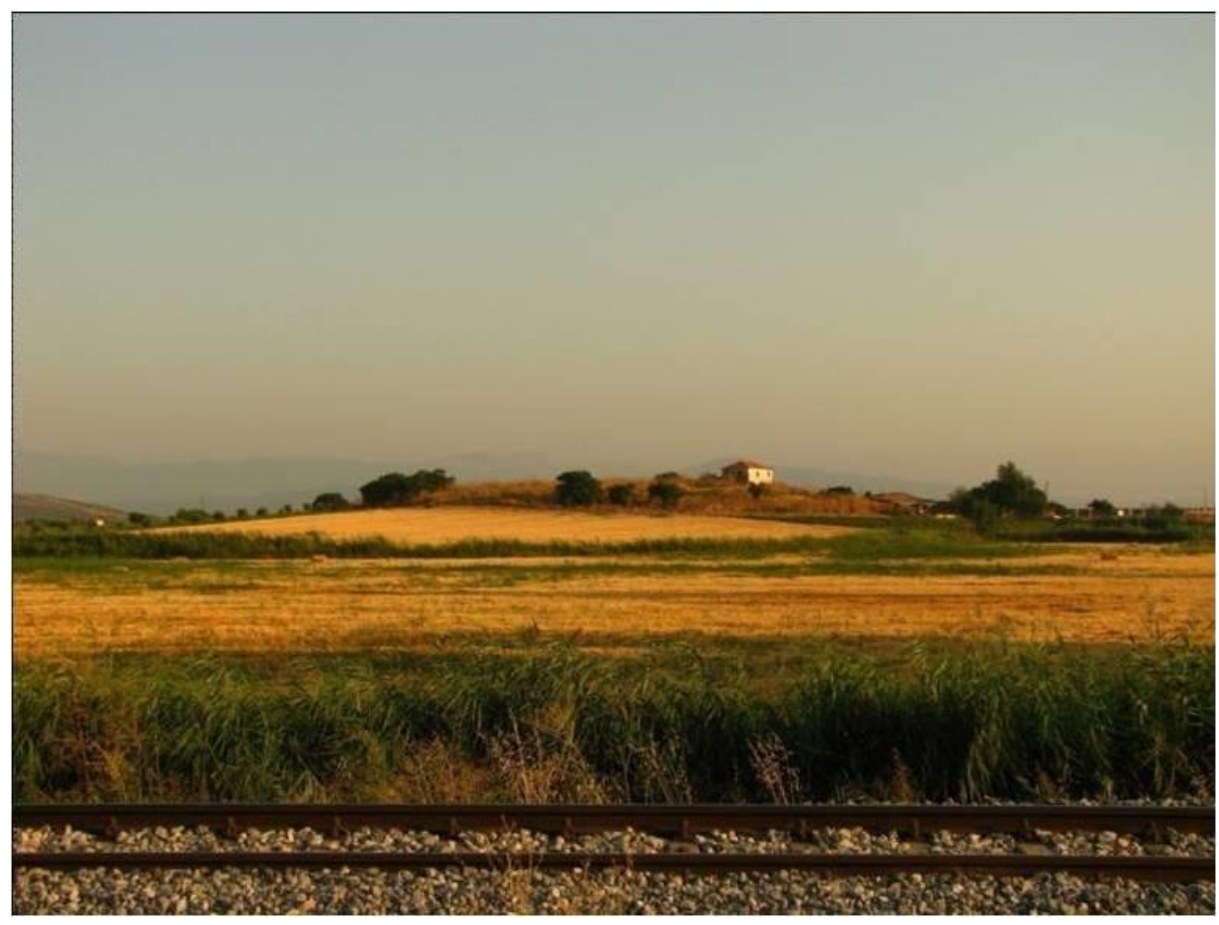


Res.4-Dağdeviren Höyüğü (Akırbey/Çakırbey Çiftliği), Akhisar.

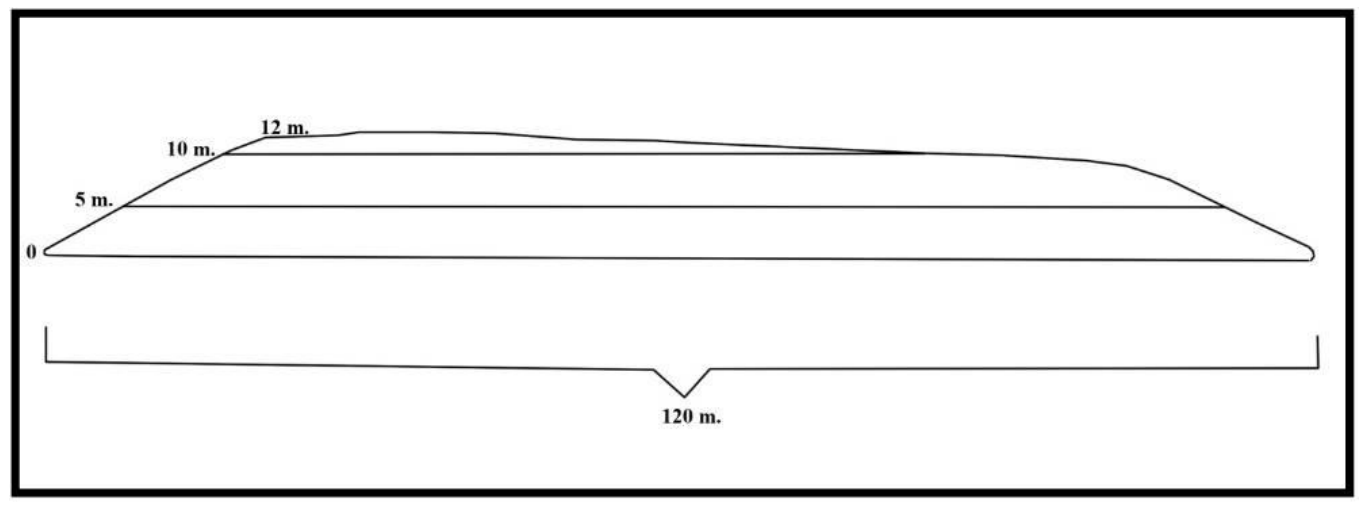

Res.5-Dağdeviren Höyüğü (Akırbey/Çakırbey Çiftliği) cephe çizimi 


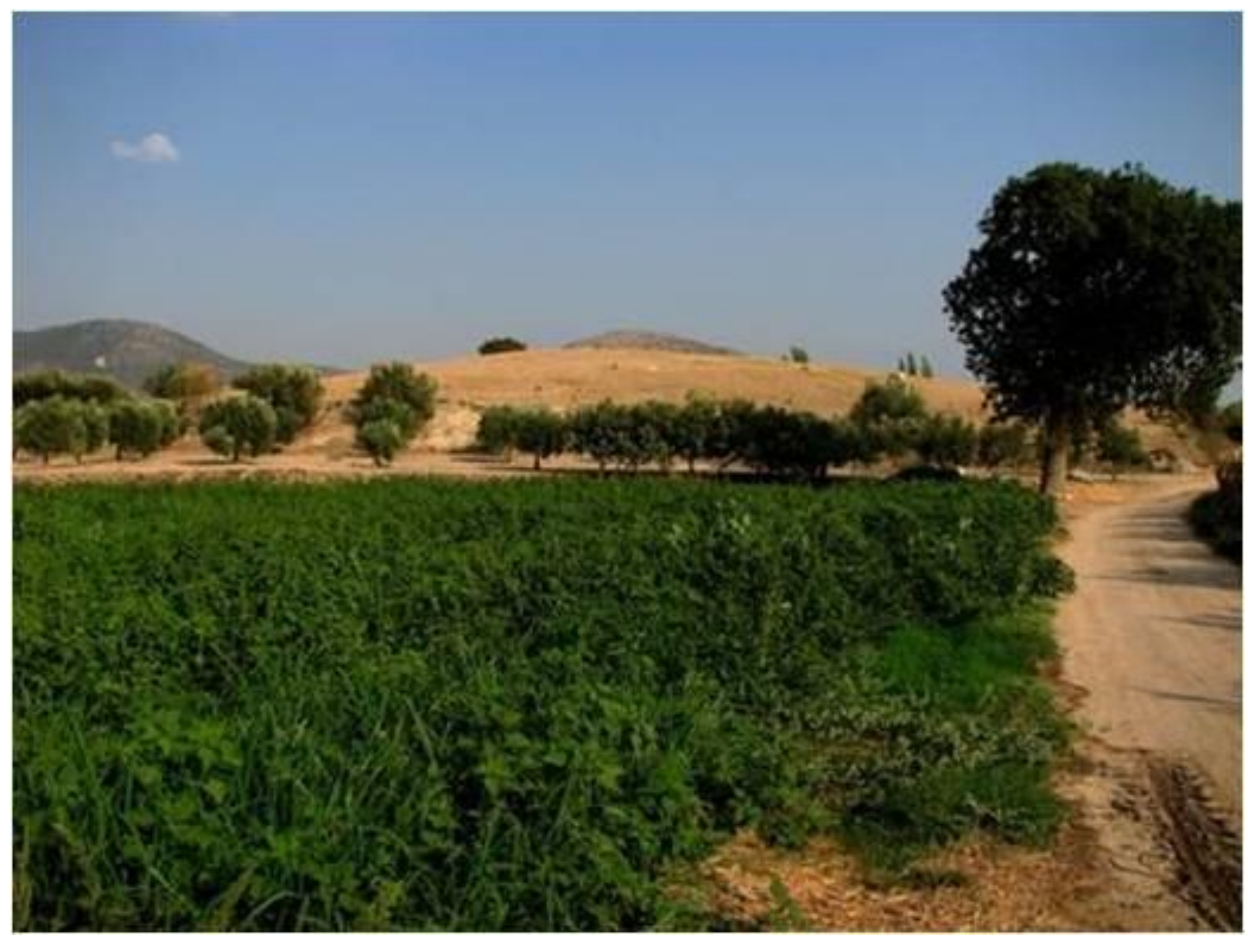

Res.6-Kennez Höyügü, Akhisar.

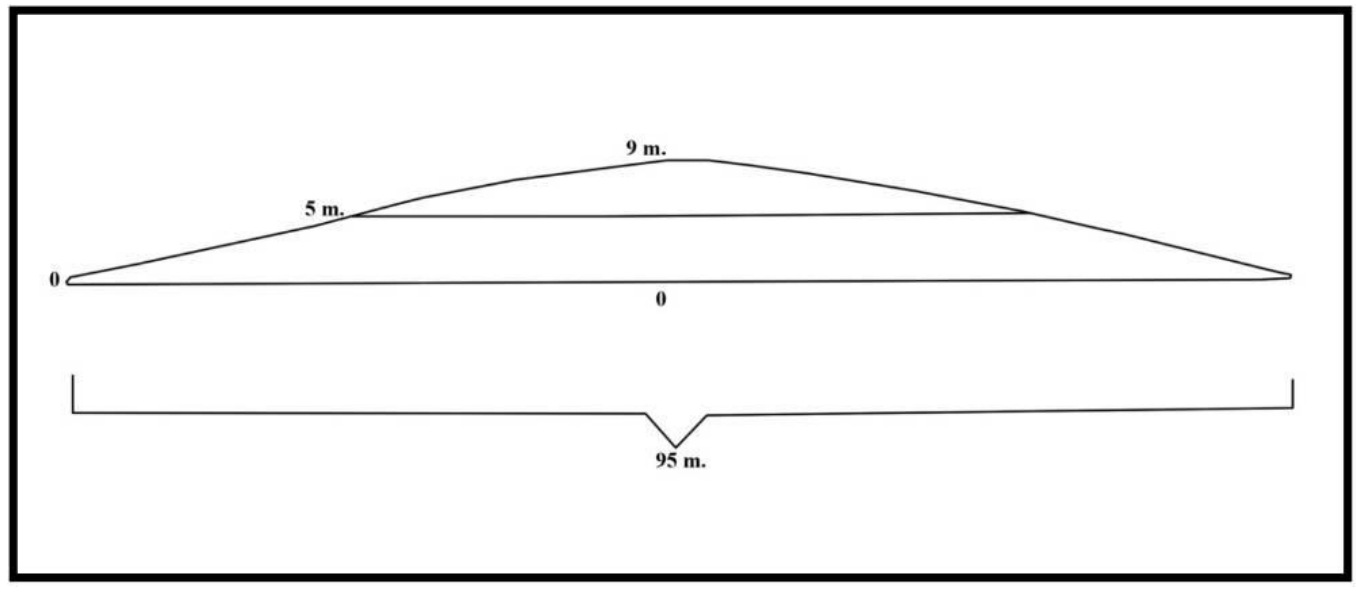

Res.7-Kennez Höyügü cephe çizimi 


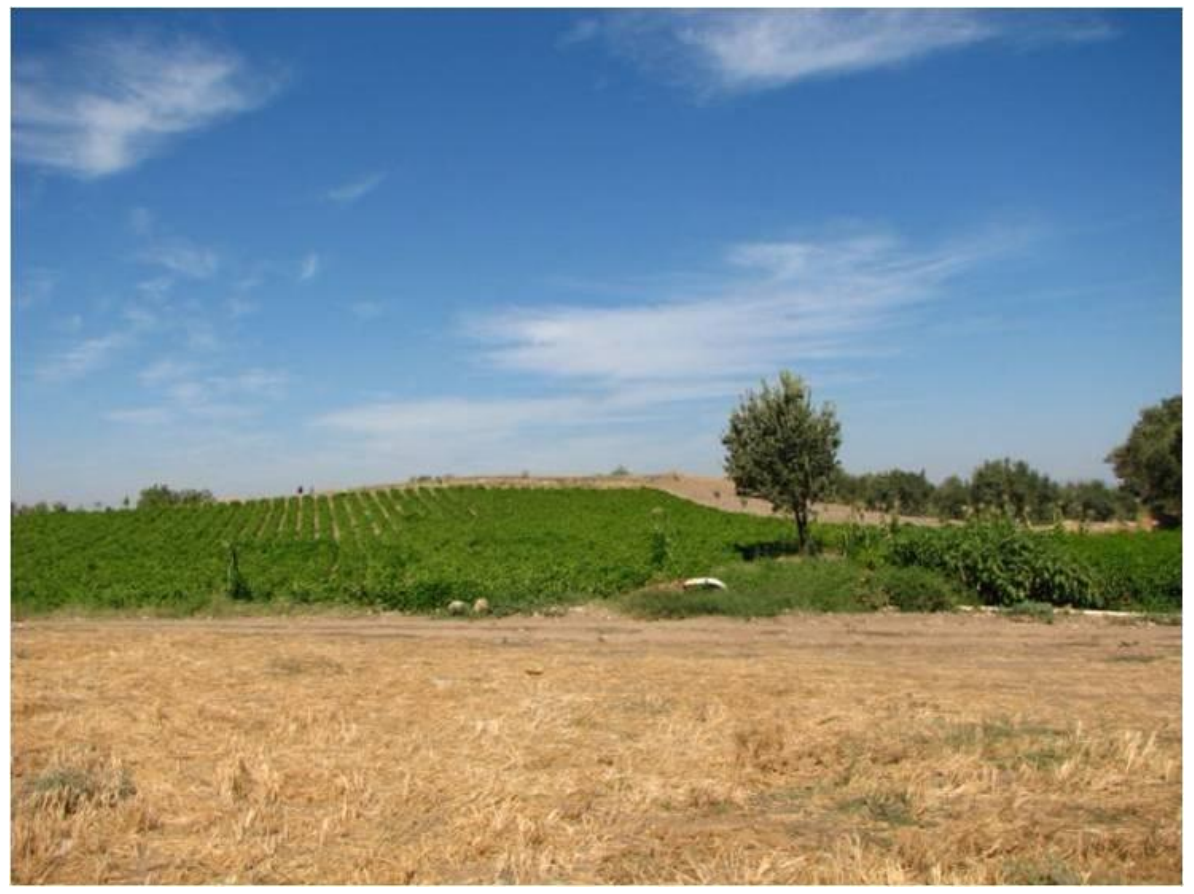

Res.8-Bedeller Höyüğü, Saruhanl1.

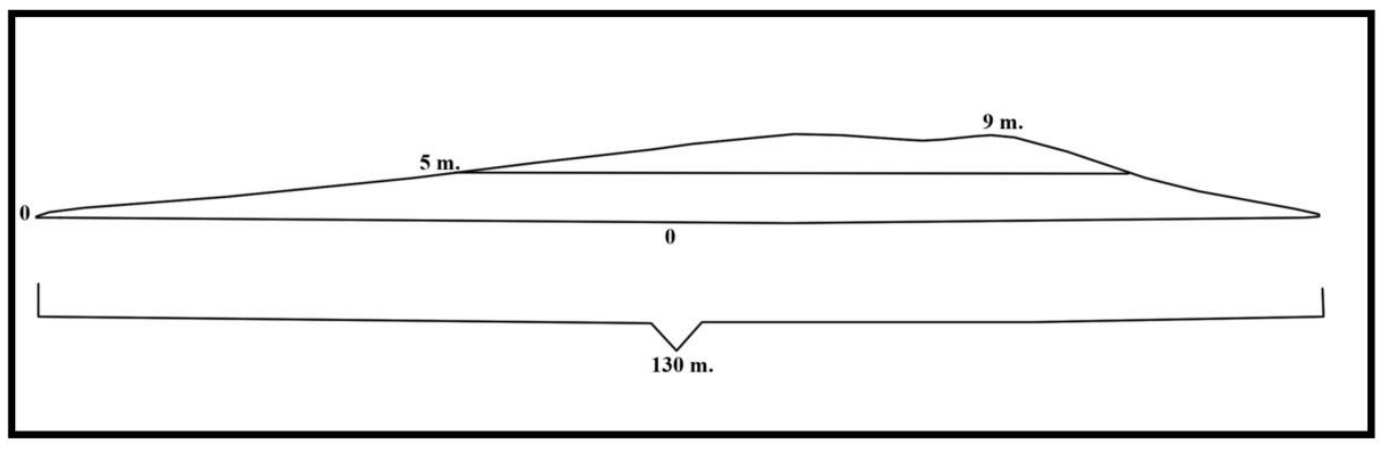

Res.9-Bedeller Höyüğü cephe çizimi 


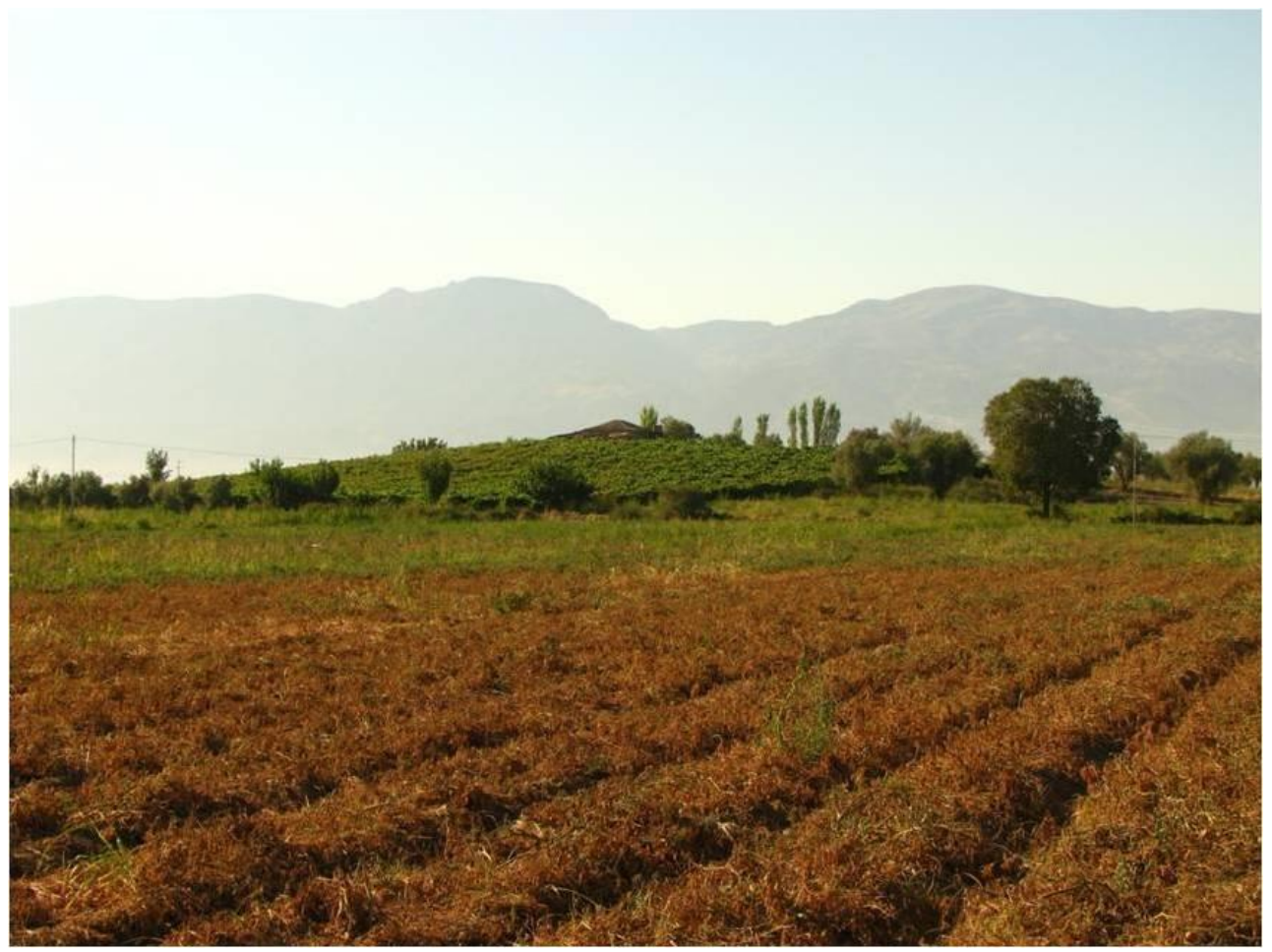

Res.10-Baklatepe Höyüğü, Muradiye.

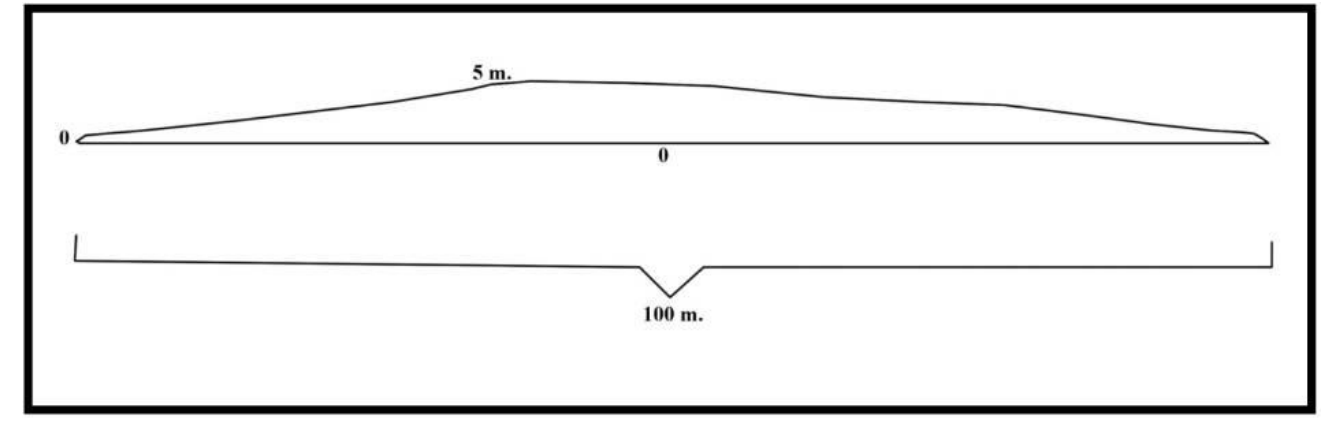

Res.11-Baklatepe Höyüğü cephe çizimi 


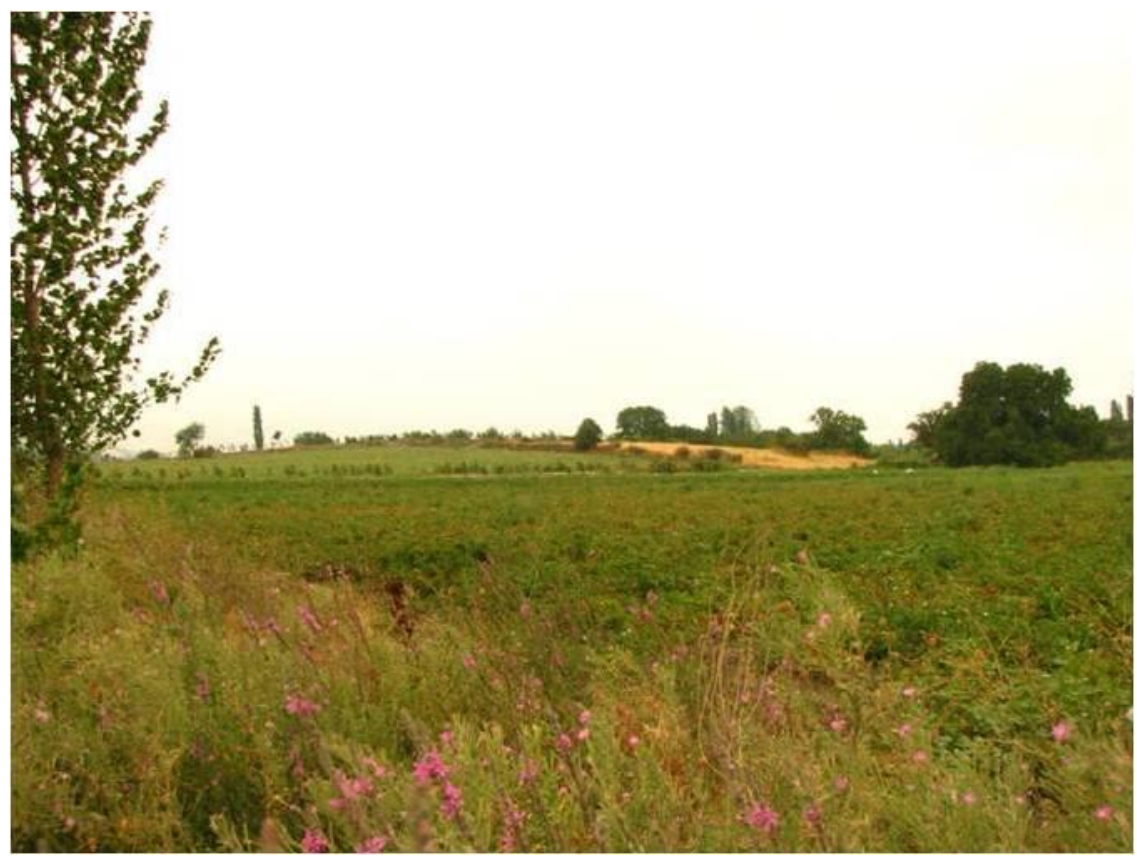

Res.12-Yağc1lı Höyüğü, Soma.

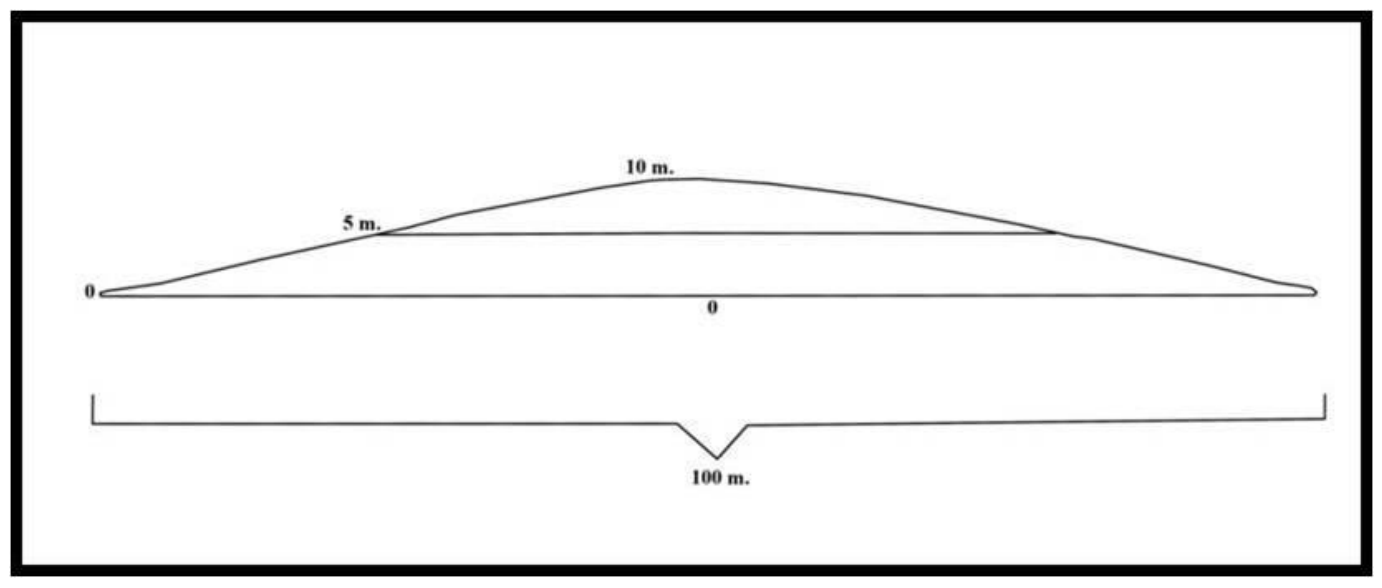

Res.13-Soma Yağc1lı Höyüğü cephe çizimi 


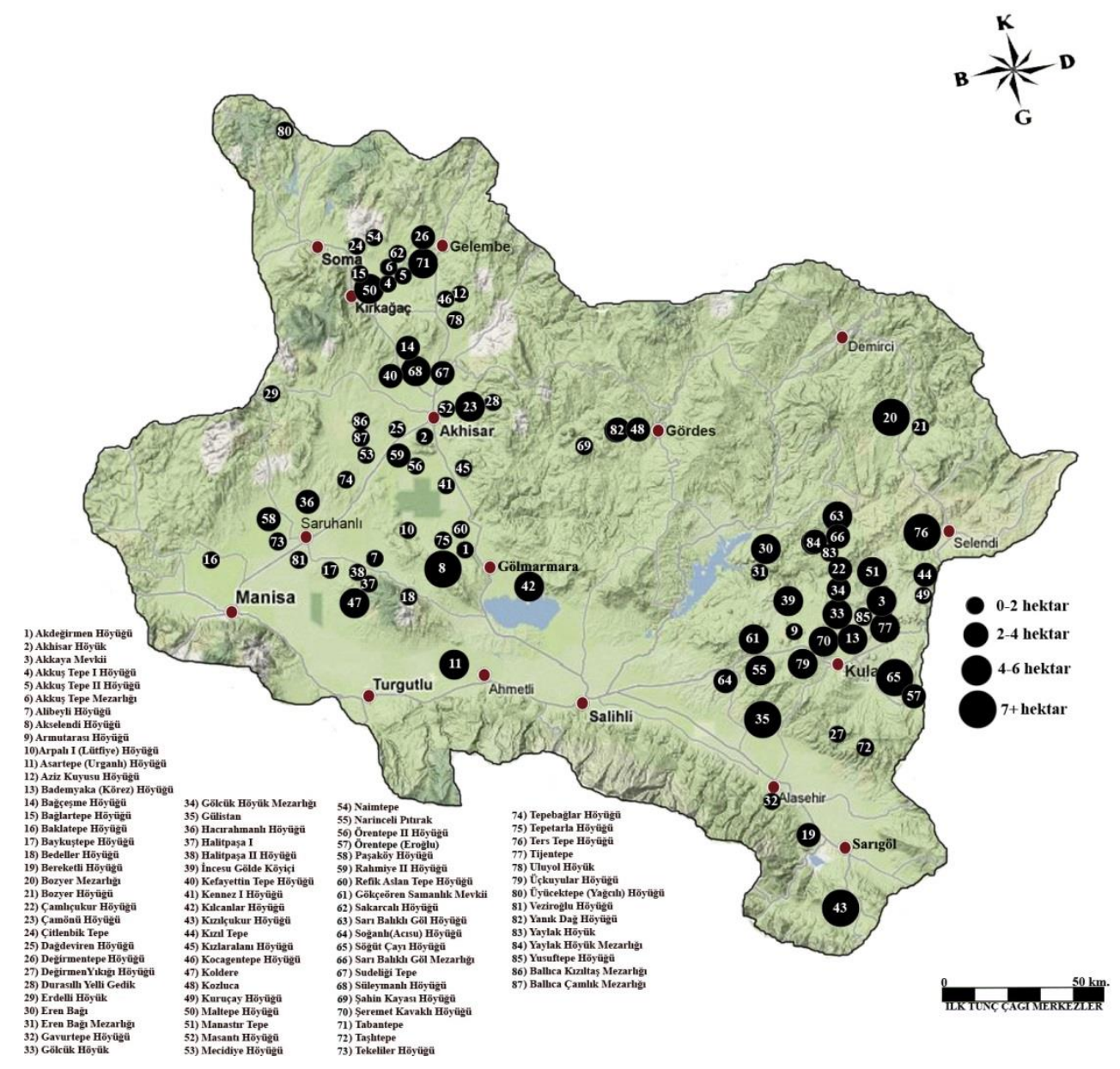

Res. 14-Manisa Yöresindeki İlk Tunç Çağı Yerleşimlerinin Boyutlarına Göre Dağılımı 


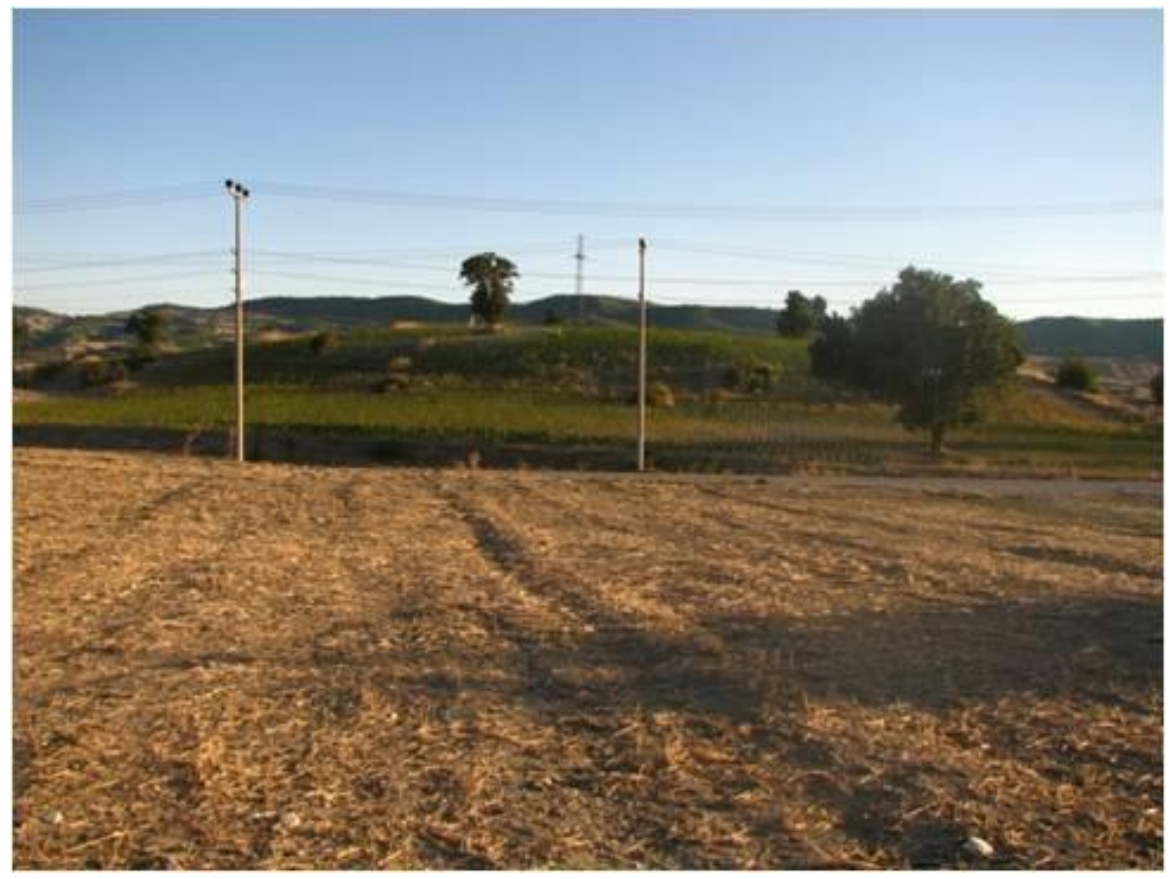

Res. 15 Ters Tepe Höyüğü, Selendi.

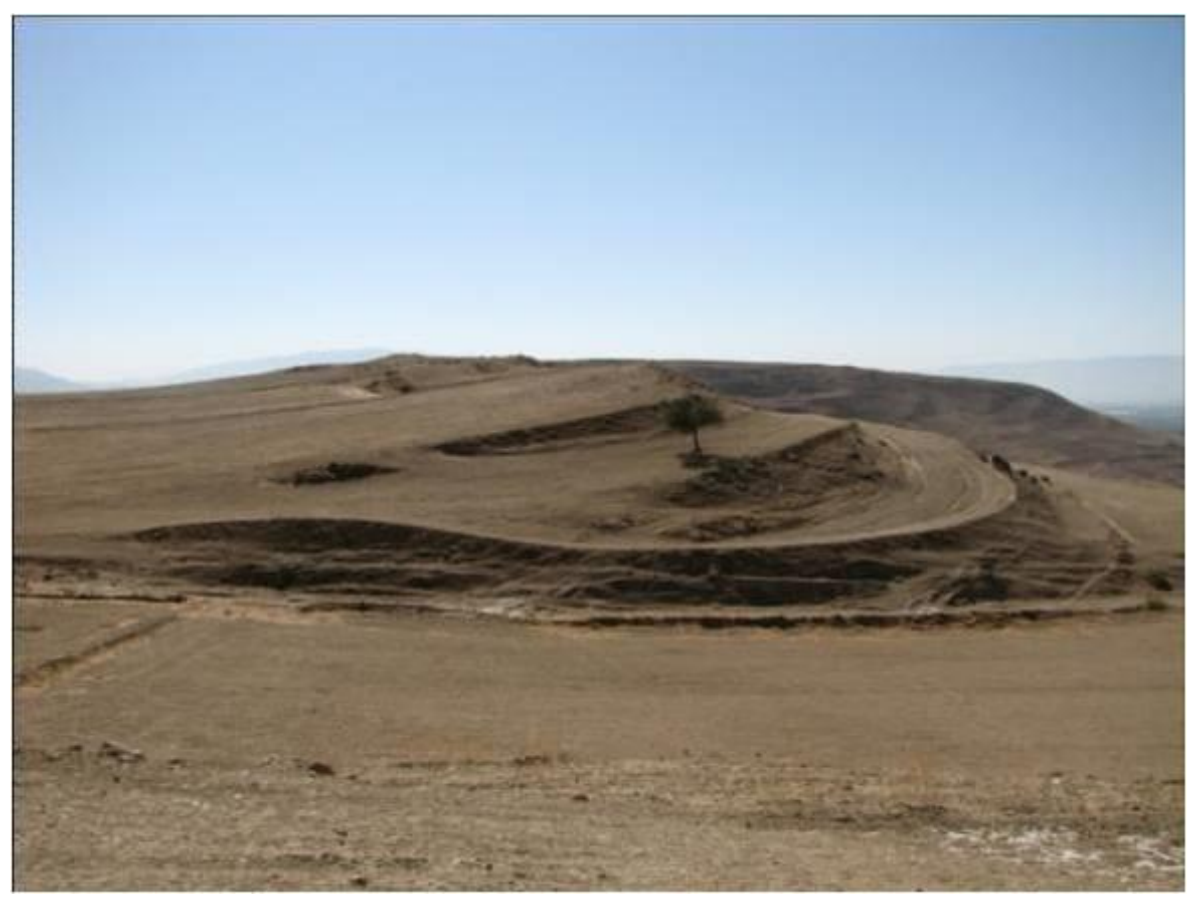

Res. 16-Taşlitepe Tepeüstü Yerleşimi, Alaşehir. 


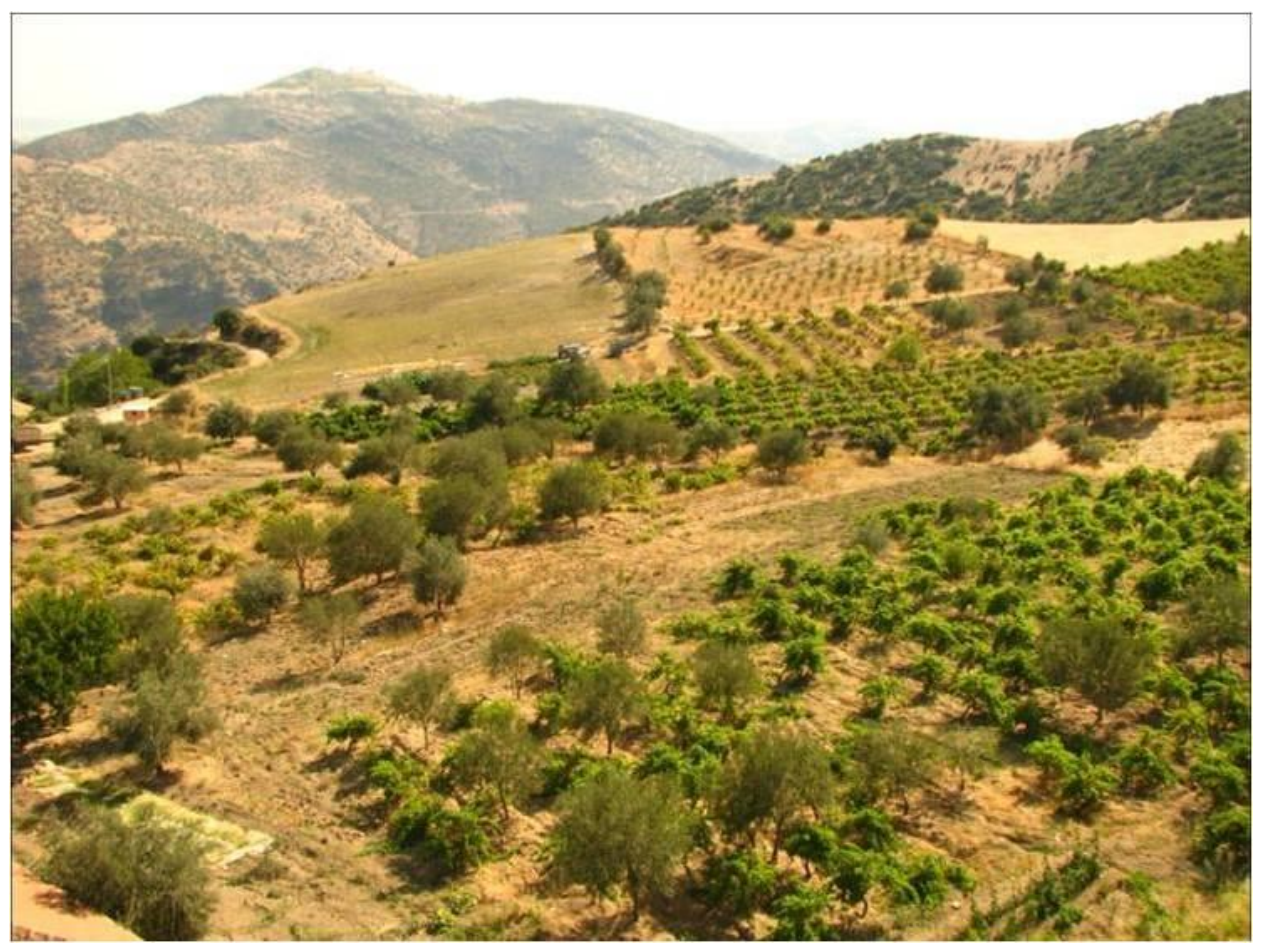

Res. 17-Erenbağı Yamaç Yerleşimi, Kula.

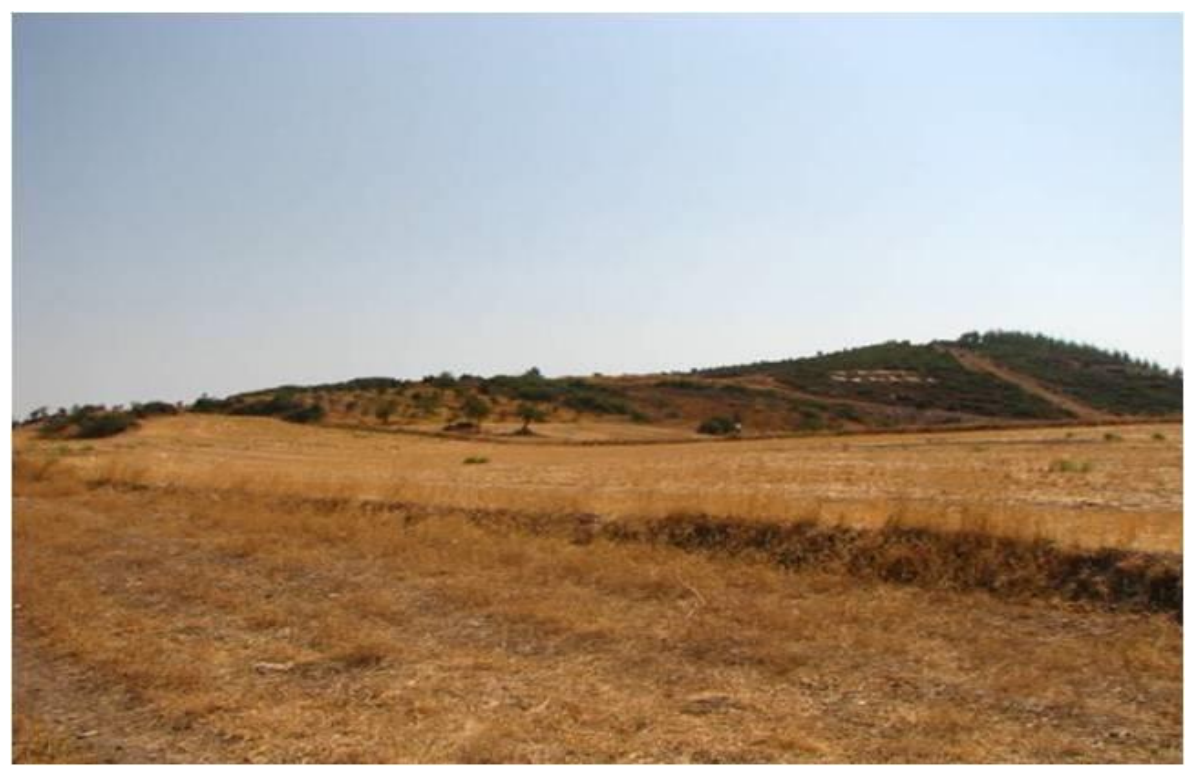

Resim 18-Kazımçeşme Yamaç Yerleşimi, Akhisar. 


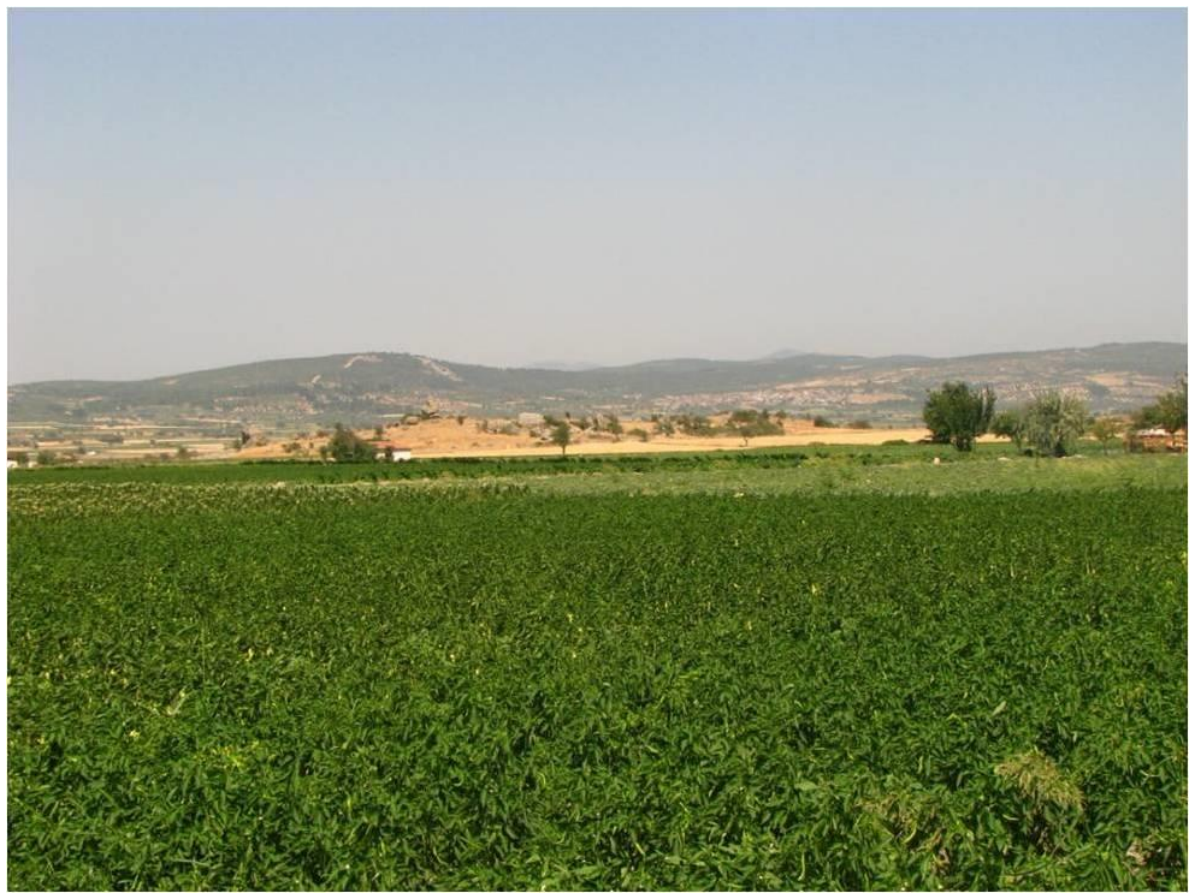

Res.19-Gaudin'in kazı yaptığı Yortan Mezarlığı, bugünkü Tabantepe. 


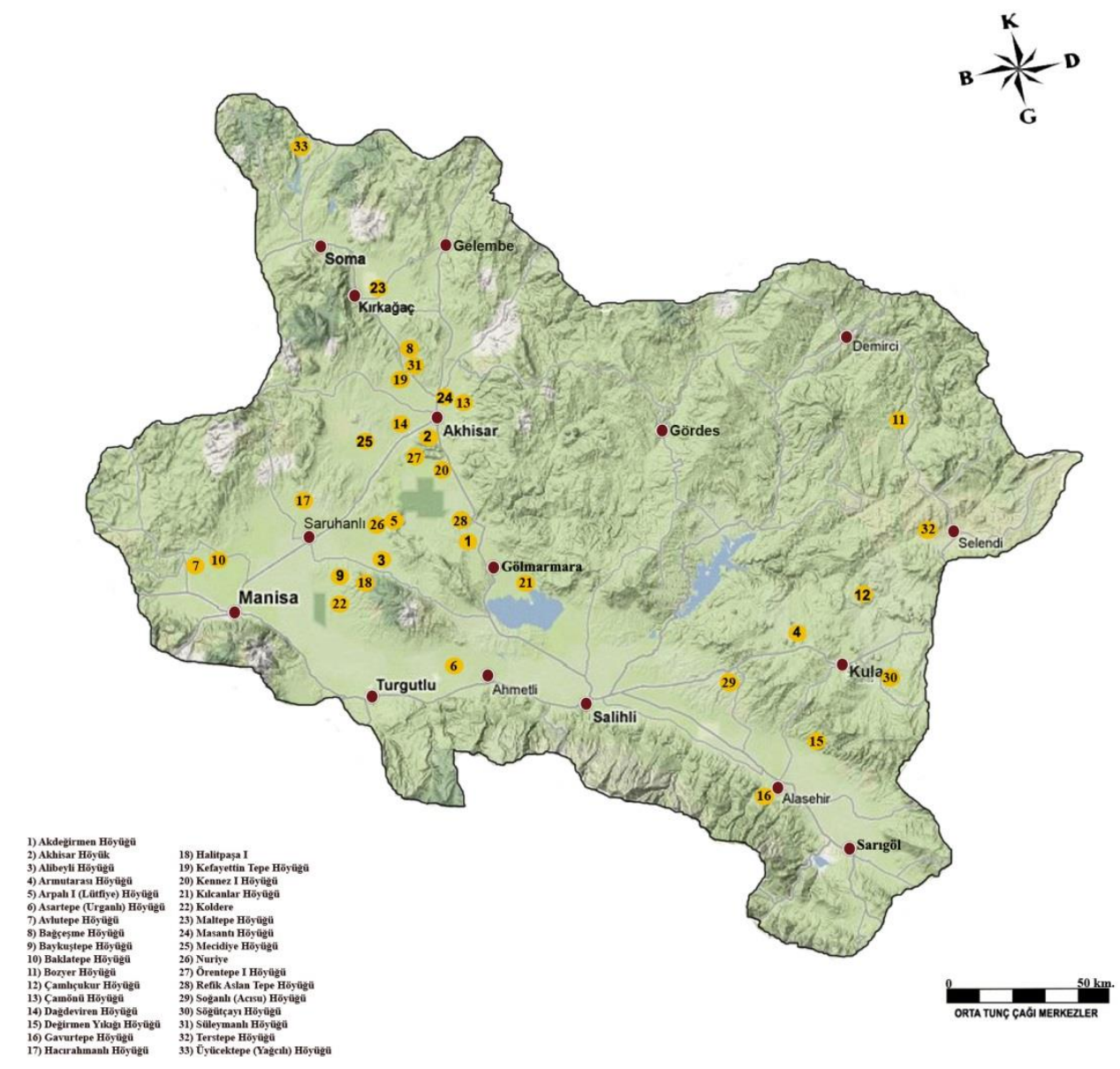

Res.20-Manisa Yöresinde Orta Tunç Çağı Buluntu Merkezleri 